\title{
Sosyal Bilgiler Öğretim Programında Yer Alan Bazı Becerilerin Kazandırılmasına Yönelik Öğretmen Görüşleri \\ Yaşar ÇELIK*
}

Öz: $\mathrm{Bu}$ araştırma öğretmenlerin, sosyal bilgiler öğretim programında yer alan becerilerin kazandırılmasına yönelik yaptıkları etkinliklerin ve programın uygulanmasında yaşadıkları sorunların tespit edilmesi amacıyla yapılmış durum çalışması deseninde nitel bir çalışmadır. Araştırma, 2019-2020 eğitim-öğretim yılında, Ordu İli Ünye İlçesi’ndeki okullarda (ilkokul, bağımsız-birleştirilmiş sınıflı ilkokul) görev yapan ve araştırmaya gönüllü olarak katılan 44 öğretmenle (31 bağımsız sınıf, 13 birleştirilmiş sınıf) gerçekleştirilmiştir. Araştırmada amaçlı örnekleme yöntemlerinden kolay ulaşılabilir durum örneklemesi kullanılmıştır. Araştırmaya farklı okullarda (bağımsız ve birleştirilmiş sınıflı) ve farklı şartlarda (köy ve şehir merkezi) görev yapan öğretmenler dâhil edilmiştir. Öğretmenlerden verilerin toplanması amaciyla, araştırmacı tarafından geliştirilen yarı yapılandırılmış görüşme formu kullanılmıştır. Verilerin analizinde, içerik analizi kullanılmıştır. Araştırmada, sosyal bilgiler öğretim programındaki becerilerin (dijital okuryazarlık, finansal okuryazarlık, girişimcilik, hukuk okuryazarlığı, politik okuryazarlık ve konum analizi ) kazandırılması konusunda yeterli açıklama ve etkinlik örneklerinin bulunmadığı, bu yaş grubundaki çocuklar için soyut kaldığı, programın uygulanması için derse ayrılan sürenin yeterli olmadığı, materyal temini konusunda sorunlar yaşandığı ve öğretmenlerin bu becerileri kazandırma konusunda yeterli olmadıkları sonuçlarına ulaşılmıştır.

Anahtar Kelimeler: Sosyal bilgiler, Öğretim programı, Beceri, Öğretmen görüşleri

\section{Teachers' Views Regarding the Acquisition of Some Skills in the Social Studies}

\section{Curriculum}

Abstract: This research is a qualitative research in the case study, carried out to determine of the problems which problems experienced by teachers for the acquisition of skills in the social studies curriculum and the problems they experience in the implementation of the program. Qualitative research methods and case study design were used in the research. The research

*Dr. Öğr. Üyesi 19 Mayıs Üniversitesi, Eğitim Fakültesi, Temel Eğitim Bölümü, E-mail:ycelik@omu.edu.tr Orcid No: 00000001-8159-5189

Bu araştırma için 19 Mayıs Üniversitesi Sosyal ve Beşeri Bilimleri Etik Kurulu Başkanlığında (05/02/2020 tarih ve 2020/61 sayılı) etik izin alınmıştır. 
was carried out with 44 teachers (31 independent classes, 13 multigrade classrooms) who work in schools (primary schools and primary school with independent-multigrade classrooms) and participants voluntarily participated in the research, in the United District of Ordu Province in the 2019-2020 academic year. Easily accessible case sampling, one of the purposeful sampling methods has been used in the research. Teachers included in the research, working in different schools (independent and combined classrooms) and under different conditions (village and city center). In the research, a semi-structured interview form developed by the researcher was used to collect data from teachers. The content analysis is used in the analysis of the data. In the research, it is concluded that there are not enough explanation and activity examples for the acquisition of skills in the social studies curriculum (digital literacy, financial literacy, entrepreneurship, legal literacy, political literacy and location analysis), the skills are abstract for children, the time allocated to the lesson is not sufficient to the implementation of the program, there are difficulties in the acquisition of the material and teachers are insufficient to teach of these skills.

Keywords: Social Studies, Curriculum, Skill, Teachers' Opinions

\section{Giriş}

Günümüzde bireylere daha etkili ve verimli bir eğitim imkânı sağlama konusunda toplumlar önemli bir arayış içindedirler. Bu amaçla dünya genelinde çokça araştırmalar yapılmaktadır. $\mathrm{Bu}$ araştırmaların sonuçları eğitim programlarına yansıtılarak hayata geçirilmeye çalışılmaktadır. Okullarda yapılan eğitim-öğretim etkinlikleri bilişsel, duyuşsal ve psikomotor özellikteki kazanımlardan oluşmaktadır. 2005 yılından bu yana sosyal bilgiler öğretim programında öğrencilere günümüz ihtiyaçlarına cevap verecek nitelikte bazı becerilerin kazandırılması hedeflenmiştir. Bu bağlamda bilişsel ve psikomotor öğrenmelerin birlikte yer aldığı süreçlerin sonunda ortaya çıkan ürünler beceri olarak adlandırılmıştır (Milli Eğitim Bakanlığı [MEB], (2005).

2005 sosyal bilgiler öğretim programında, Türkçe’yi doğru, güzel ve etkili kullanma, araştırma, değişim ve sürekliliği algılama, iletişim, karar verme, girişimcilik, eleştirel düşünme, yaratıcı düşünme, problem çözme, sosyal katılım ve empati, bilgi teknolojilerini kullanma, gözlem, mekânı algılama ve zaman ve kronolojiyi algılama becerilerine yer verilmiştir (MEB, 2005). 2017 ve 2018 sosyal bilgiler öğretim programlarında bu becerilere finansal okuryazarlık, dijital okuryazarlık, kalıp yargı ve önyargıyı fark etme, konum analizi, yenilikçi düşünme, medya okuryazarlığı, tablo, grafik ve diyagram çizme ve yorumlama, iş 
birliği, çevre okuryazarlığı, değişim ve sürekliliği algılama, kanıt kullanma, özdenetim ve politik okuryazarlık ve harita ve hukuk okuryazarlığı becerileri eklenmiştir. 2018 öğretim programında 'yaratıcı düşünme' ve 'sebep-sonuç ilişkisini belirleme' becerilerine yer verilmezken; dijital okuryazarlık, finansal okuryazarlık ve medya okuryazarlığı becerileri programa yerleştirilmiştir. Bu becerileri programa yerleştirerek 2005 programındaki etkili vatandaş yetiştirme konusundaki eksikliklerin tamamlanması amaçlanmıştır (Tay, 2017).

Sosyal bilgiler öğretim programında yer alan becerilerden biri dijital okuryazarlıktır. Martin'e (2005) göre dijital okuryazarlık, bireylerin dijital araçlara erişimi, bu araçları kullanması, yönetmesi analiz, sentez ve değerlendirme yapması; yeni bilgiyi yapılandırması, başkaları ile iletişim kurması ve bunların sağlayacağı imkânları ifade eder. Diğer bir ifadeye göre dijital okuryazarlık, yaygınlaşan dijital teknoloji aracığıyla gençlerin sosyal yaşama daha güvenli bir şekilde katılmalarını sağlama aracıdır (Hague \& Payton, 2011). Sosyal bilgiler öğretim programında (MEB, 2018) dijital yetkinlik, günlük hayat, çalışma ve iletişim amacıyla bilgi iletişim teknolojilerinin güvenli bir şekilde kullanılması, bilgiye erişim imkânları ve ulaşılan bilgilerin eleştirel bir bakış açısıyla değerlendirilmesi; bilginin üretilmesi, kullanılması, saklanması ve sunulması maksadıyla bilgisayarların kullanılması ile internet vasıtasıyla ortak ağlara bağlanarak iletişim kurma olarak ifade edilmiştir. Sosyal bilgiler dersinde öğrencilere kazandırılması beklenen diğer bir beceri girişimciliktir. Girişimcilik, bireyin çevresinde oluşan firsatları fark etmesi ve bu firsatlardan en iyi şekilde yararlanabilmek için gerektiğinde risk alarak plan ve projeler yapması ve bunları hayata geçirebilmek için gerekli çabayı göstermesi olarak tanımlanabilir (Gömleksiz ve Kan, 2009). Başka bir ifade ile bireyin hayallerini gerçeğe dönüştürme çabasıdır (Hisrich \& Peters, 2002; Ürper, 2015). Sosyal bilgiler öğretim programında bu beceri bilim, teknoloji ve toplum öğrenme alanı ile ilişkilendirilmiştir. Bu beceriyi kazandırmak için örnek girişimciler ve onların başarı öyküleri üzerinde durulmasını önerilmiştir (MEB, 2018). Girişimcilik becerisinin erken yaşlarda kazandırılması ilerleyen yaşlarda bireyin hayatında ve kariyerlerinde önemli firsatları yakalamasına katkılar sağlayacaktır (Chell, 2015). Cünkü, girişimcilik doğuştan kazanılan bir özellik değil, ancak öğrenmeyle kazanılan bir beceridir (Van Praag, Huber \& Sloof, 2012). İlkokul çağındaki çocuklara kazandırılacak girişimcilik becerisi genel de ticari anlamda kullanılan girişimcilikten ziyade; o yaş düzeyinde okul ortamında yakalayacağı fırsatları fark etme, mevcut kaynakları organize etme, proje üretme ve ürettiği projeleri hayata geçirmek için gerekli özveri ve çabayı gösterme becerilerini ihtiva etmektedir (MEB, 2009). 
Politik okuryazarlık; bireylerin toplumsal yaşamın bir parçası olan politik süreçler konusunda temel bilgilerle donanması ve eleştirel düşünme becerisine sahip olması olarak tanımlanabilir. Bu bakımdan toplumda yaşayan bütün bireylere politik süreçlerden doğrudan ya da dolaylı olarak etkilendiği fikri verilmelidir (Tarhan, 2015). Politik okuryazarlık becerisinin gelişmesi için ilkokuldan hatta okul öncesinden itibaren öğrencilere katılım firsatının verilmesi gerekir. Politik okuryazarlık, sosyal bilgiler dersinin etkili vatandaş yetiştirme amacına yönelik bir beceridir. Dolayısıyla öğrencilere kazandırılması gereken en temel becerilerden biri olduğu söylenebilir (Gençtürk ve Karatekin, 2013). Bu beceri daha çok etkin vatandaşlık öğrenme alanı içinde ele alınmaktadır. Bu kapsamda öğrencilere kuvvetler ayrılığı ilkesi ile yasama, yürütme ve yarg1 güçlerinin her birinin kendine has yetki ve sorumluluklarının olduğu; siyasi partiler, sivil toplum kuruluşları, medya ve bireyler (kamuoyu) kavramlarının ele alınması önerilmektedir (MEB, 2018).

Hukuk okuryazarlığı toplumsal yaşamı düzenleyen hukukla ilgili terimleri doğru bir şekilde anlamak ve gerektiğinde uygun şekilde kullanmaktır (Alkaya ve Yağl1, 2015). Günümüzde hukuksal okuryazarlık kavramı, hukuk sistemi ile etkili bir iletişim kurmak için gerekli tüm bilgi ve becerileri içermektedir. Hukuk okuryazarlığı aynı zamanda sosyal bilgiler öğretim programının, etkin, üretken, hak ve sorumluluklarını bilen ve kullanan vatandaşlar yetiştirebilmek hedeflerini gerçekleştirmek için öğrencilerin hukuk okuryazarı olmasını istemektedir (MEB, 2004).

Uluslararası Öğrenci Değerlendirme Programı (PISA), finansal okuryazarlı̆̆ı; bireylerin ve toplumun finansal refah düzeyini artırmak için, finansla ilgili temel kavramları, riskleri ve becerileri anlama; bu bilgi ve anlayışı gerektiğinde finansal konularda alınacak kararlarda kullanma beceri ve güvenine sahip olmak farklı finansal bağlamlarda etkili kararlar almak için kullanma güdüsü ve güvenine sahip olmak olarak tanımlamıştır (OECD, 2012). Bu bağlamda sosyal bilgiler dersinde pazar yerine, finans kuruluşlarına yapılacak geziler öğrencilerin bilgiyi yapılandırması, diğer bir ifadeyle finansal okuryazarlık kazanmasına önemli katkılar sağlayabilir (Akengin ve Ersoy, 2015). Sosyal bilgiler öğretim programında finansal okuryazarlık, üretim, dağıtım ve tüketim öğrenme alanı kapsamında ele alınmaktadır. $\mathrm{Bu}$ öğrenme alanında öğrencilere gelir, gider, bütçe, üretim, dağıtım, tüketim ve meslek gibi kavramları kullanarak öğrencilerin yakın çevresindeki ekonomik faaliyetleri gözlemlemesi ve raporlaştırılması ile ilgili çalışmalar yapmaları önerilmiştir (MEB, 2018). Bu öğrenme alanının temelini öğrencilerin girişimci ve bilinçli tüketici becerilerinin geliştirilmesi oluşturur. Bu bağlamda sosyal bilgiler dersinde finansal okuryazarlık açısından sınırlı olan 
ülke kaynaklarının korunması ve geliştirilmesine yönelik olumlu tutum geliştirme, arkadaşları ile kendi ekonomik durumunu mukayese etme, meslekleri gelecekte yapacağı meslek tercihi açısından inceleme ve bulunduğu yerin ekonomik şartlarını gözden geçirerek geliştirmeye yönelik çaba gösterme gibi özelliklerin kazanılması beklenmektedir (Çubukçu ve Bayzan). Bu yüzden finansal okuryazarlık eğitimi bazı ülkelerde müstakil ders olarak ilkokul düzeyinde başlamaktadir (Orton, 2007).

Konum, yeryüzünde bir noktanın, enlem ve boylamların yardımıyla bulunan yer, konuş (Türk Dil Kurumu Sözlüğü [TDK], (1932) olarak tanımlanmaktadır. Konum analizi bireylerin bulundukları mekanla ilgili bilişi olarak ifade edilebilir. Biliş, insan zihninin dünyadaki olayları anlamaya yönelik işlemler bütünüdür (Senemoğlu, 2001). İlköğretim düzeyinde mekân ve konumla ilgili kavramların öğretilmesi çok önemlidir. Bu bağlamda konum, mesafe, yön, açı, ölçek, mekânsal uyum, mekânsal hiyerarşi ve mekânsal ilişki gibi kavramlar kazandırılmalıdır. Bu beceri önceki programlarda harita okuryazarlığı, mekânı algılama vb. beceriler olarak diğer beceriler içerisine yedirilerek kazandırılması amaçlanmıştı (Çepni, 2015). Sosyal bilgiler öğretim programında konum analizi insanlar, yerler ve çevreler öğrenme alanı kapsamında ele alınmaktadır. Bu öğrenme alanının amacı, öğrencilerin çevresi ile etkileşim kurma, kurduğu etkileşimin neden ve sonuçları üzerinde düşünerek bireysel ve toplumsal bakış açısı kazanmalarıdır. Bununla birlikte, jeopolitik, iklim ve ulaşım gibi konularda ülkemizin özellikleri konusunda çıkarımda bulunmaları; mekânı algılama, konum analizi, diyagram çizme ve yorumlama becerileri kazanmaları hedeflenmektedir (MEB, 2018).

Öğretim programları öğrencilere kazandırılacak bilgi, beceri ve tutumların hangi amaçla, hangi düzeyde, ne kadar sürede ve nasıl kazandırılacağını ve nasıl değerlendirileceğini gösteren ayrıntılı bir plan olup, öğretim programlarındaki hedeflere ulaşabilmek için ne öğretileceği sorusunun cevabını da taşımaktadır. Bu bağlamda mevcut sosyal bilgiler programına bakıldığında öğrencilere kazandırılması öngörülen bazı becerilere yer verilmiştir. Öğretim programında, bu becerilerin programda yer alan kazanımlarla eşleştirildiği vurgulanarak, öğretmenin bu eşleştirmeyi dikkate alarak kazanımlarla birlikte becerileri de kazandırması gerektiği vurgulanmaktadır. Kazanımlarla becerilerin eşleştirilmesinin, becerileri kazandırma açısından yeterli olup olmadığ becerileri kazandırma yönünden gerekli bilgi ve becerilere sahip olup olmadıkları konusunda literatürde yeterli araştırmaya rastlanmamaktadır. Öğretmenlerin, özellikle sosyal bilgiler öğretim programında yer alan bazı becerileri anlama ve uygulamada zorlandıklarını 
vurgulamalarından yola çıkılarak böyle bir araştırma yapmaya ihtiyaç duyulmuştur. $\mathrm{Bu}$ araştırmayla becerilerin kazandırılması ile ilgili olarak öğretmenlerden ne beklendiği, öğretmenlerin söz konusu becerilerden ne anladıkları, becerileri kazandırmak için ne tür etkinlikler yaptıklarının tespit edilmesi amaçlanmıştır. Dolayısıyla bir yandan durum tespiti yapılırken, diğer yandan da tespit edilen iyi örneklerin paylaşılması amaçlanmaktadır. Araştırmada aşağıdaki sorulara yer verilmiştir.

1. Programda yer alan dijital okuryazarlık becerisini kazandırma konusunda yaptığınız çalışmalar ve karşılaştığınız sorunlar nelerdir?

2. Programda yer alan finansal okuryazarlık becerisini kazandırma konusunda yaptığınız çalışmalar ve karşılaştığınız sorunlar nelerdir?

3. Programda yer alan girişimcilik becerisini kazandırma konusunda yaptığınız çalışmalar ve karşılaştığınız sorunlar nelerdir?

4. Programda yer alan hukuk okuryazarlığı becerisini kazandırma konusunda yaptığınız çalışmalar ve karşılaştı̆̆ınız sorunlar nelerdir?

5. Programda yer alan politik okuryazarlık becerisini kazandırma konusunda yaptı̆̆ınız çalışmalar ve karşıllaştığınız sorunlar nelerdir?

6. Programda yer alan konum analizi becerisini kazandırma konusunda yaptığınız çalışmalar ve karşılaştığınız sorunlar nelerdir?

\section{Yöntem}

\section{Araştırmanın Deseni}

$\mathrm{Bu}$ araştırma; öğretmenlerin, sosyal bilgiler öğretim programında yer alan bazı becerilerin kazandırılmasına yönelik yaptıkları etkinlikleri, uygulama esnasında yaşadıkları sorunları tespit etmek ve meslektaşlar arasında paylaşmak amacıyla yapılmış durum çalışması deseninde nitel bir çalışmadır. Durum çalışması, araştırmacı tarafından kontrol edilemeyen olgu ya da olayların nasıl ve niçin soruları temele alınarak derinliğine incelenmesine ve bunlarla ilgili tespitlerde bulunmaya dayanan araştırma yöntemidir (Yıldırım ve Şimşek, 2011). Sosyal bilgiler öğretim programında birtakım becerilerin öğrencilere kazandırılması gerektiği vurgulanmış ancak bu becerilerin kazanılıp kazanılmadığı ya da ne düzeyde kazanıldığı konusu tartışma konusu olmuştur. $\mathrm{Bu}$ çalışmada, öğretmenlerin sosyal bilgiler öğretim programında yer alan becerileri kazandırmak amacıyla izledikleri stratejiler, yaşadıkları sorunlar çeşitli boyutlarıyla ele alınarak incelenmiş ve paydaşların hizmetine sunulmaya çalışılmıştır. 


\section{Çalışma Grubu}

Bu araştırma, 2019-2020 eğitim-öğretim yılında, Ordu İli Ünye İlçesi’ne bağl1 okullarda görev yapan, araştırmaya katılmaya gönüllü 70 öğretmenle gerçekleştirilmiştir. Araştırmada amaçlı örnekleme yöntemlerinden kolay ulaşılabilir durum örneklemesi kullanılmıştır. Bu örnekleme yöntemi, varlığından emin olunduğu halde kolay ve hızlı ulaşılamayan unsurlar için kullanılır. Çoğu kez nitel araştırmalarda kullanılan örneklem büyüklüğünün genelleme yapmaya uygun olmadığı düşüncesinden hareketle, çalışılması kolay ve pahalı olmayan durumlar tercih edilmektedir (Patton, 2005; Vogt, Gardner \& Haeffele, 2012; Yıldırım ve Şimşek, 2011). Araştırmanın amacına hizmet etmesi bakımından farklı okullarda (bağımsız ve birleştirilmiş sınıflı) ve farklı şartlarda (köy ve şehir merkezi) görev yapan öğretmenlerin araştırmaya katılmasına çalışılmıştır. Araştırmaya katılan öğretmenlerin 54'ü bağımsız sınıflı 16'sı ise birleştirilmiş sınıflı okullarda görev yapmaktadır.

\section{Veri Toplama Aracı}

Araştırmacının farklı zamanlarda öğretmenlerle yaptığı sohbetlerde sosyal bilgiler öğretim programında yer alan bazı becerileri anlama ve uygulamada zorlandıklarını vurgulamalarından yola çıkılarak böyle bir araştırma yapmaya ihtiyaç duyulmuştur. Araştırma verilerini toplamak amacıyla açık uçlu sorulardan oluşan bir form kullanılmasına karar verilmiştir. Açık uçlu sorular araştırmacıya araştırma konusunda esneklik sağlamasının yanında konu ile ilgili önemli değişkenlerin dikkatten kaçmasını da engeller (Yıldırım ve Şimşek, 2011). Araştırma sorularını hazırlamak amacıyla alanla ilgili bazı kaynaklar (Gürel, 2017; Güvenç, 2015; MEB, 2018; Orton, 2007; Sözen ve Ada, 2018; Tarhan, 2015; Tay, 2017) gözden geçirilerek 8 araştırma sorusu oluşturulmuştur. Oluşturulan sorular, sosyal bilgiler ve eğitim bilimleri alanında ikişer ve Türkçe alanından bir olmak üzere beş akademisyen tarafından incelenmiş ve onların önerilerine göre yeniden düzenlenmiştir. $\mathrm{Bu}$ bağlamda, sosyal bilgiler alanındaki uzmanlar bazı soruların benzer içeriğe sahip olduğu yönünde görüş belirtmeleri üzerine o sorular birleştirilerek yeniden düzenlenmiştir. Oluşturulan sorularla, iki dördüncü sınıf öğretmeni üzerinde pilot uygulama yapılmıştır. Uygulama araştırmacının da bulunduğu ortamda yapılmış, öğretmenlerden sorularda anlaşılmayan bir durum olduğunda anında sormaları istenmiştir. Uygulamada anlamakta zorlanılan iki husus düzeltilerek sorulara son şekli verilmiştir. Veriler 2019-2020 öğretim yılında Ordu İl'i Ünye İlçesi'nde bulunan resmi ilkokullarda görev yapan 4. sınıf 
öğretmenleriyle, 4. sınıfı da içinde barındıran birleştirilmiş sınıf okutan öğretmenlerden elde edilmiştir. Bunun için MEB'den ve buna bağlı olarak Ordu İl Milli Eğitim Müdürlüğü'nden uygulama izni alınmıştır. Uygulamada görev alacak yetkililere gerekli açıklamalar yapılmış olup bu doğrultuda öğretmenlere formun doldurulması konusunda gerekli bilgilendirme yapılmıştır. Soru formu, cevaplandırmak için gönüllü olan katılımcılara verilmiştir. Katılımcıların soruları yönlendirme olmaksızın cevaplamaları sağlanmıştır.

\section{Verilerin Analizi}

Veriler içerik analizi kullanılarak analiz edilmiştir. Araştırmaya katılan 70 öğretmenden 26'sından bazılarının formu yeterince doldurmadıkları, bazılarının ise konu dışında cevaplar yazdıkları için analize alınmamıştır. Böylece 44 öğretmenden (31 bağımsız sınıf, 13 birleştirilmiş sınıf) elde edilen veriler analize tabi tutulmuştur. Analizden önce tarama ölçütleri belirlenerek kodlamaların bu ölçütlere göre yapılması sağlanmıştır. Bu bağlamda yapılan kodlamalar sonucunda bazı temalara, daha sonra oluşturulan temalar alt temalara ve kategorilere ayrılmıştır. Kodlama çalışmalarında araştırmacının dışında nitel araştırma konusunda deneyimli başka bir araştırmacının da araştırmacıdan bağımsız olarak kodlama yapması sağlanmıştır. Bireylerin görüşlerinden doğrudan alıntılara yer verilerek görüşlerin etkili bir biçimde yansıtılmasına çalışılmıştır. Araştırmada öğretmenler Ö1, Ö2, Ö3...şeklinde kodlanmıştır. İçerik analiziyle birbirine benzeyen verilerle çeşitli kavramlar temalar çerçevesinde bir araya getirilir ve daha sonra bunlar okuyucunun anlayacağı bir tarzda yorumlanmaya çalışılır (Büyüköztürk, Çakmak-Kılıç, Akgün, Karadeniz ve Demirel, 2008; Cohen, Manion, \& Morrison 2007; Y1ldırım ve Şimşek, 2011).

Nitel araştırmalarda güvenirliğin sağlanmasında veriler üzerinde birden çok araştırmacının verdiği kodlar arasındaki kararlılık esas alınmaktadır (Creswell, 2013). Bu bağlamda araştırmacıların, soruların her biriyle ilgili yaptıkları kodlamalar karşılaştırılarak görüş birliği ve görüş ayrılığı olarak düzenlenmiştir. Araştırmacıların birbirlerine yakın anlamda kullandıkları kodlar görüş birliği; anlam itibariyle birbirinden oldukça farklı veya benzerliğine karar vermekte tereddüde düşülen kodlar ise görüş ayrılığı olarak kararlaştırılmıştır. Üzerinde görüş birliğine varılamayan kodlar araştırma dışında bırakılmıştır. Daha sonra sorulara verilen cevaplarla ilgili uyuşum yüzdesi (Güvenirlik) = Görüş birliği/(Görüş Birliği+Görüş Ayrılığı)x100 formülü kullanılarak hesaplanmıştır (Miles \& Huberman, 1994). Uyuşum Yüzdesi $($ Güvenirlik $)=161 /(161+33) 100$ işleminden yaklaşık 0,83 
YYÜ Eğitim Fakültesi Dergisi (YYU Journal of Education Faculty), 2021; 18(1)733-765,http://efdergi.yyu.edu.tr,

olarak tespit edilmiştir. Uyuşum yüzdesinin 0,70’ten yüksek çıkması yeterli olarak kabul edilmektedir (Yıldırım ve Şimşek, 2011).

\section{Bulgular}

Araştırmaya katılan öğretmenlerin sosyal bilgiler öğretim programında yer alan dijital okuryazarlık becerisini kazandırma konusunda yaptıkları ekinlikler ve uygulama sırasında karşılaştıkları sorunlarla ilgili görüşleri Tablo 1'de sunulmuştur. 
Tablo 1. Dijital okuryazarlık becerisi kazandırmak amacıyla yapılan uygulamalar ve uygulama sırasında karşılaşılan sorunlar

\begin{tabular}{|c|c|}
\hline & Yapılan etkinlikler \\
\hline Teorik & Pratik \\
\hline 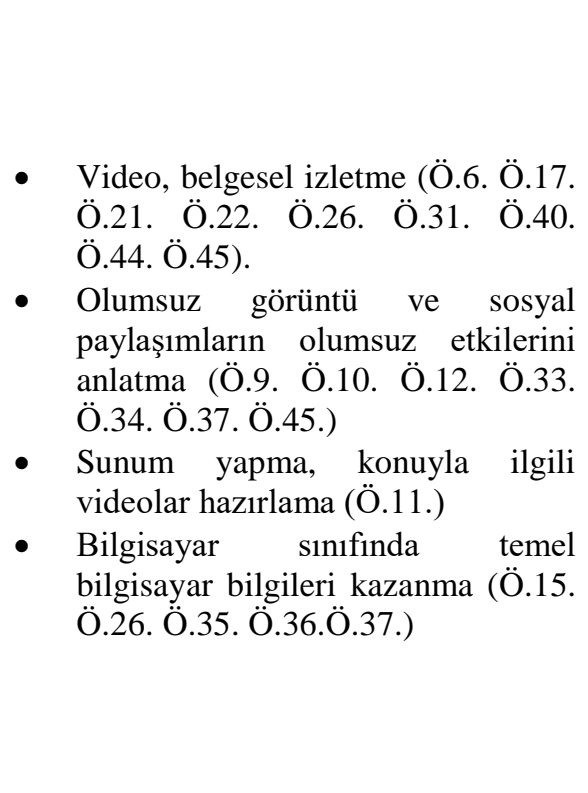 &  \\
\hline
\end{tabular}

\begin{tabular}{|c|c|c|}
\hline \multicolumn{3}{|c|}{ Karşılaşılan sorunlar } \\
\hline Aileden kaynaklanan & Öğrenciden kaynaklanan & $\begin{array}{c}\text { Öğretim programı, çevre, okul ve öğretmenden } \\
\text { kaynaklanan }\end{array}$ \\
\hline $\begin{array}{l}\text { - } \quad \text { Veli müdahalesinin } \\
\text { olumsuz sonuç } \\
\text { doğurması (Ö.3). } \\
\text { - Yeterli veli desteği } \\
\text { sağlanamaması } \\
\text { (Ö.34). }\end{array}$ & 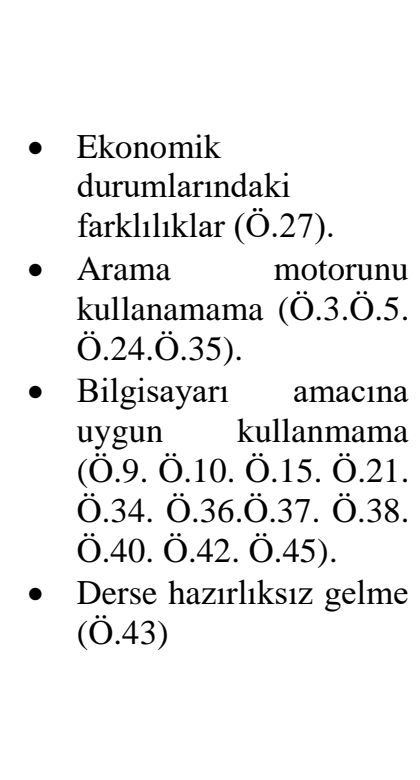 & 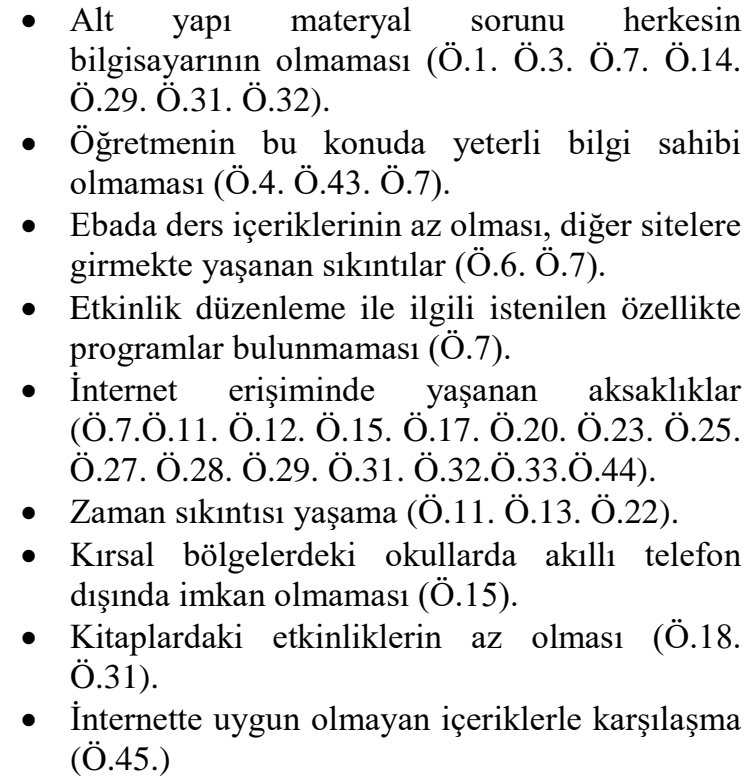 \\
\hline
\end{tabular}

Tablo 1 incelendiğinde, öğretmenlerin öğrencilere dijital okuryazarlık becerisi kazandırmak amacıyla yaptıkları etkinlikler teorik ve pratik olmak üzere iki alt kategoriye; karşılaştıkları sorunlar ise veliden, öğrenciden ve öğretim programı, çevre, okul ve öğretmenden kaynaklanan sorunlar olmak üzere üç alt kategoriye ayrılarak analiz edilmiştir. Bunlardan öğretmenler teorik anlamda en çok konuyla ilgili video ve belgesel izletme ve 
olumsuz görüntü ve sosyal paylaşımların olumsuz etkilerini anlattıklarını belirtmişlerdir. Pratik olarak ise en çok slayt hazırlatıp sunu yaptırma, araştırma-inceleme ve bilginin paylaşımı amacıyla bilgisayar kullanma, Morpa Kampus yazılım programından destek alma vurgulanmıştır. Sorunlar sayıca en çok olanlarına bakıldığında; veliden yeterince destek sağlanamaması, öğrencilerin bilgisayarı amacına uygun kullanmaması, internet erişiminde aksaklıklar yaşanması, alt yapı ve materyal sorunu, herkesin bilgisayarının olmaması, öğretmenin bu konuda yeterli bilgi sahibi olmaması ve zaman yetersizliği olarak ifade edilmiştir. Öğretmenlerin görüşlerinden bazıları aşağıda gösterilmiştir.

Ö.17: Sosyal bilgiler konularlyla ilgili video, belgesel izletiyorum.

Ö.28: Morpa Kampus, EBA gibi internet sayfalarından interaktif içerikler sunmak, deneme sinavlart ve testler yamak; deney ve belgeseller izletmek, Kahaot uygulaması kullanarak oyun tabanl yanıt sistemi oluşturmak. Farklı kaynaklardan araştırmalar yaparak sunum yapmalarını sağlamak.

Ö.32: Okulumuz nispeten kırsal okul olduğu için ögrenciler sadece anne ya da babaların akıllı telefonlarını kullanabiliyorlar, bunun haricinde dijital araç gereçlere ev ortamında sınırlı ulaşabiliyorlar.

Araştırmaya katılan öğretmenlerin sosyal bilgiler öğretim programında yer alan finansal okuryazarlık becerisini kazandırma konusunda yaptıkları etkinlikler ve uygulama sırasında karşılaştıkları sorunlarla ilgili görüşleri Tablo 2'de sunulmuştur.

Tablo 2. Finansal okuryazarlık becerisi kazandirmak amaciyla yapılan uygulamalar ve uygulama sırasında karşılaşılan sorunlar

\begin{tabular}{|c|c|}
\hline & Yapılan etkinlikler \\
\hline Teorik & Pratik \\
\hline $\begin{array}{l}\text { - Temel kavramlarla ilgili } \\
\text { video izletme (Ö.6. } \\
\text { Ö.20.Ö.22.Ö.27. Ö.39.) } \\
\text { - Konuyu anlatıp özetini } \\
\text { yazdırma (Ö.30.) } \\
\text { - Çeşitli ülkelerin para } \\
\text { birimleri ve ekonomik } \\
\text { göstergeler konusunda bilgi } \\
\text { verme, alışverişte ahlaki } \\
\text { değerleri anlatma (Ö.31.) } \\
\text { Konu ile ilgili kanun ve } \\
\text { kuralları kavratma } \\
\text { (Ö.31.Ö.36.) } \\
\text { Etkinlik yaptırmadım, bilgi } \\
\text { sahibi değilim (Ö.4. Ö.14. } \\
\text { Ö.25.) }\end{array}$ & 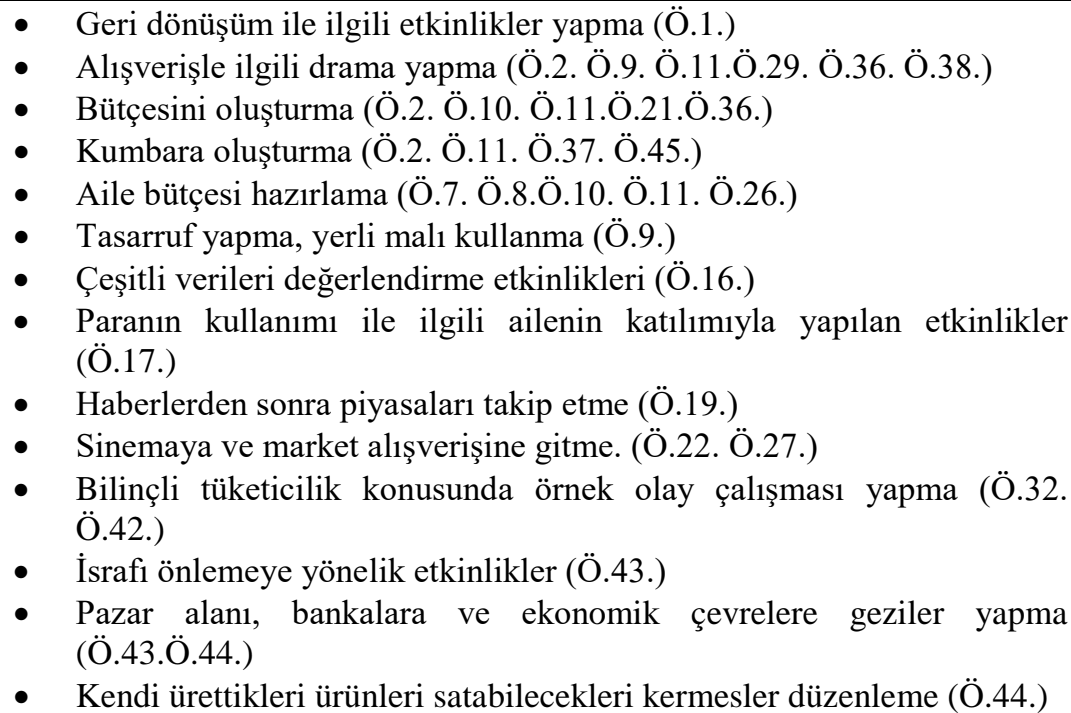 \\
\hline
\end{tabular}




\begin{tabular}{|c|c|c|}
\hline \multicolumn{3}{|c|}{ Karşılaşılan sorunlar } \\
\hline Aileden kaynaklanan & Öğrenciden kaynaklanan & $\begin{array}{c}\text { Öğretim programı, çevre, okul ve öğretmenden } \\
\text { kaynaklanan }\end{array}$ \\
\hline 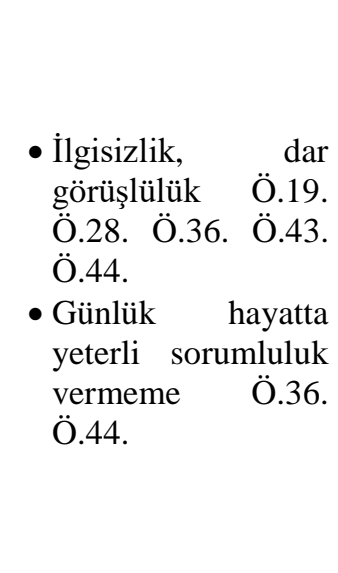 & $\begin{array}{l}\text { - Kumbara çalışmasının } \\
\text { yeterince etkili } \\
\text { olmamasıö.3. Ö.7. } \\
\text { - Reklamların etkisinde kalma } \\
\text { Ö.4 } \\
\text { - Tasarruf eğilimlerinin çok } \\
\text { düşük olması Ö.6.Ö.41. } \\
\text { - Harcama konusunda } \\
\text { yeterince bilinçli olmama } \\
\text { Ö.3.Ö.9. Ö.13. Ö.43. Ö.45. } \\
\text { - Çalışmalara katılmada } \\
\text { isteksizlik Ö.14. ö.18. } \\
\text { - Parasal konulardan çabuk } \\
\text { sikılma Ö.26. Ö.32. }\end{array}$ & $\begin{array}{l}\text { - Konunun ilkokul için soyut olması Ö.1. Ö.36. } \\
\text { - Uygulama yapmak için ders süresinin yetersiz } \\
\text { kalması Ö.10. Ö.11. Ö.22. Ö.27. Ö.32. } \\
\text { - Sınıf düzeyinin üzerinde olması Ö.17. } \\
\text { - Kitaplardaki konuların yeterince açık olmaması } \\
\text { Ö.30. } \\
\text { - Materyal eksikliği ve çevre şartlarının yetersiz } \\
\text { olması Ö.31. } \\
\text { - Birleştirilmiş sınıflarda alışveriş yapacakları } \\
\text { kantin bulunmaması Ö.35. } \\
\text { - Yaş grubunda isteklerin ihtiyaçların önüne } \\
\text { geçmesi Ö.21.Ö.38. Ö.45. } \\
\text { - Okul diş1 gezilerde güvenlik problemleri } \\
\text { vasama Ö.45. }\end{array}$ \\
\hline
\end{tabular}

Tablo 2 incelendiğinde öğretmenlerin öğrencilere finansal okuryazarlık becerisi kazandırmak amacıyla yaptıkları etkinlikler teorik ve pratik olmak üzere iki alt kategoriye, karşılaştıkları sorunlar ise veliden, öğrenciden, öğretim programı, çevre, okul ve öğretmenden kaynaklanan sorunlar olmak üzere üç alt kategoriye ayrılarak analiz edilmiştir. Bunlardan öğretmenlerin teorik anlamda en çok tasarruf, bütçe, gelir gider ve tasarruf kavramları ile ilgili video izletme; pratik olarak ise en çok alışverişle ilgili drama yapma, ailesinin ve kendi bütçesini oluşturma ve kumbara oluşturma etkinliklerini yaptıkları anlaşılmaktadır. Sorunların sayıca en çok olanlarına bakıldığında; velinin konu ile ilgili çocuklarına yeterli paylaşımda bulunmaması, sorumluluk vermemesi, öğrencilerin harcama konusunda yeterince bilinçli olmaması, tasarruf eğilimlerinin çok düşük olması, uygulama yapmak için ders süresinin yetersiz kalması ve bu yaş grubunda isteklerin ihtiyaçların önüne geçmesi olarak belirtildiği görülmektedir. Öğretmenlerin görüşlerinden bazıları aşağıda gösterilmiştir.

Ö.22: Ö̆ğrencilerime derste ellerindeki parayı nasıl değerlendirebileceklerine dair anlattığım teorik bilgileri içeren dersimi sinema ve market alışverişine götürerek ve orada kendi ücretlerini ödemelerini, para üstünü hesaplamalarını isteyerek uygulamaya döktüm.

Ö.37: Kumbara kullanımı, istek ve ihtiyaçlarımızı öğrenmeye yönelik alış-veriş, drama vb. etkinlikler, sonuçları ve süreçleri sınıfta tartışılıyor.

Ö.27: Zaman konusunda sıkıntı yaşadık. Alacakları ürünün bedelini hesaplamakta ve para üstünü hesaplamakta fazla zamana ihtiyaç duyuyorlar. Öğrencilerin büyük çoğunluğunun hiç para kullanmıyor oluşu, alışveriş yapmamaları, yaşlarının küçük 
YYÜ Eğitim Fakültesi Dergisi (YYU Journal of Education Faculty), 2021; 18(1)733-765,http://efdergi.yyu.edu.tr,

olmasından dolayı harçlık almıyor olmaları, kumbara alışkanliğı edinmelerine ve tasarrufu uygulamalarina engel oluyor.

Araştırmaya katılan öğretmenlerin sosyal bilgiler öğretim programında yer alan girişimcilik becerisini kazandırma konusunda yaptıkları etkinlikler ve uygulama sırasında karşılaştıkları sorunlarla ilgili görüşleri Tablo 3’te sunulmuştur.

Tablo 3. Girişimcilik becerisi kazandırmak amacıyla yapılan uygulamalar ve uygulama sırasında karşılaşılan sorunlar

Teorik

\section{Yapılan etkinlikler}

Pratik
- Çeşitli iş kollarında öncü olan kişilerden örnekler verme Ö.6.Ö.31. Ö.15.

- Milli ruh ve girişimcilik bilgisi verme Ö.8.

- Yeni şeyler ortaya koyma ve maddi kazanç sağlamanın faydalarını anlatma Ö.35.Ö.38.

- Aileleri çocuklarıyla çeşitli ekonomik faaliyetlere katma konusunda özendirme (Ö.39.)

- Etkinlik yaptırmadım Ö.10. Ö.25.
- Çevre ile ilgili proje hazırlama Ö.1. Ö.2. Ö.44.

- $\quad$ Drama Ö.3. Ö4. Ö.11.Ö.32. Ö.36.

- Girişimcilik hikâyelerini ve başarı öykülerini araştırmalarını sağlamak Ö.6. Ö.28. Ö.35.

- Cesaretli, hesaplı ve ölçülü olmaya yönelik etkinlikler yapma Ö.9. Ö.42.

- Dersle ilgili sorumluluk verme Ö.13.Ö.17.

- Girişimcilik alanları ile ilgili araştırma yapma Ö.15. Ö.30.

- Girişimcilik ile ilgili yazı yazdırma ve poster hazırlatma Ö.20.

- Günlük hayatta karşılaşabilecekleri sorunlar üzerinde tartışma Ö.3. Ö.21.Ö.22. Ö.27.

- Okul meclis başkanlığı seçiminde aday olan öğrencileri destekleme Ö.22. Ö.26. Ö.27.

- $\quad$ Kitaptaki etkinlikleri yapma Ö.23.Ö.24.

- Alanında uzman kişileri sınıfa getirme Ö.26.

- Özgüvenlerini geliştirmeye yönelik çalışmalar yapma Ö.33.Ö.36.

- Topluma hizmet çalışmalarına katılma (Ö.33.)

- $\quad$ Risk alabilecekleri grup çalışmaları yapma Ö.14. Ö.36. Ö.39.

\begin{tabular}{|c|c|c|}
\hline \multicolumn{3}{|c|}{ Karşılaşılan sorunlar } \\
\hline Veliden kaynaklanan & Öğrenciden kaynaklanan & $\begin{array}{c}\text { Öğretim program, çevre, okul ve öğretmenden } \\
\text { kaynaklanan }\end{array}$ \\
\hline $\begin{array}{l}\text { - Veli katkısı } \\
\text { sağlayamama } \\
\text { Ö.1. } \\
\text { • Ailelerin çocuğa } \\
\text { baskı yapması, } \\
\text { özgüven } \\
\text { verememesi } \\
\text { Ö.13.Ö.33.Ö.36. }\end{array}$ & 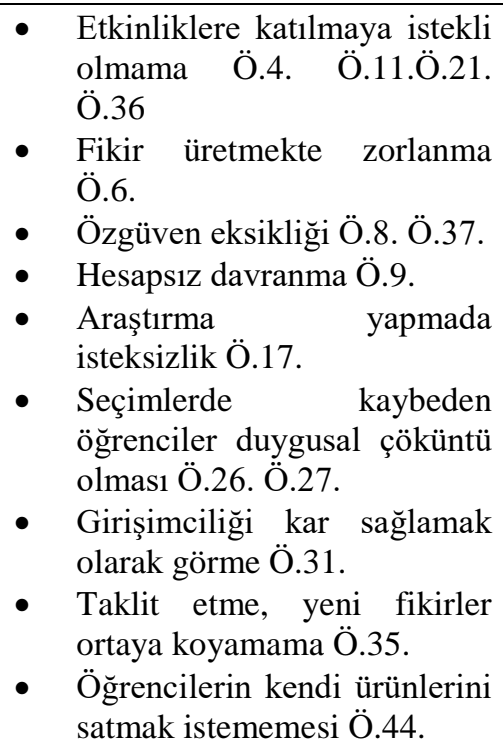 &  \\
\hline
\end{tabular}


Tablo 3'e bakıldığında öğretmenlerin öğrencilere girişimcilik becerisi kazandırmak amacıyla yaptıkları etkinlikler teorik ve pratik olmak üzere iki alt kategoriye, karşılaştıkları sorunlar ise veliden, öğrenciden, çevre, öğretim programı, okul ve öğretmenden kaynaklanan sorunlar olmak üzere üç alt kategoriye ayrılarak analiz edilmiştir. Öğretmenler teorik anlamda en çok çeşitli iş kollarında öncü olan kişilerden örnekler verme ve yeni şeyler ortaya koyma ve maddi kazanç sağlamanın faydalarını anlattıklarını; pratik olarak ise en çok drama, çevre ile ilgili proje hazırlama, girişimcilik alanları ile ilgili araştırma yapma, günlük hayatta karşılaşabilecekleri sorunlar üzerinde tartışma gibi etkinlikleri yaptıklarını belirtmişlerdir. Sorunlar sayıca en çok olanlarına bakıldığında; velilerin çocuklarına özgüven verememesi, öğrencilerin etkinliklere katılmaya istekli olmaması, zaman yetersizliği ve öğretmenin öğrencinin özgün fikirler üretmesini engellemesi olarak vurgulanmıştır. Öğretmenlerin görüşlerinden bazıları aşağıda gösterilmiştir.

Ö.31: Çeşitli iş kollarında öncü olan kişilerden örnekler veriyorum. Onların girişimcilik hikayelerini ve başarı öykülerini araştırmalarını sağlıyor ve sınıfta bu hikayeleri paylaşıyorum....

Ö.12: Girişimcilik becerisi kazandırmak için kırsal kesimde çok büyük örnek ve imkanlar yok

Ö.44: Öğrencilerin kendi ürünlerini satmak istememesi, sınıf içerisinde uyum problemi yaşayan ya da hep kendi istediği olsun isteyen ögrencilerin organizasyonu bozmasl

Araştırmaya katılan öğretmenlerin sosyal bilgiler öğretim programında yer alan hukuk okuryazarlığ becerisini kazandırma konusunda yaptıkları etkinlikler ve uygulama sırasında karşılaştıkları sorunlarla ilgili görüşleri Tablo 4'de sunulmuştur.

Tablo 4. Hukuk okuryazarlığı becerisi kazandırmak amaciyla yapılan uygulamalar ve uygulama sırasında karşılaşılan sorunlar

\begin{tabular}{|c|c|}
\hline \multicolumn{2}{|c|}{ Yapılan etkinlikler } \\
\hline Teorik & Pratik \\
\hline 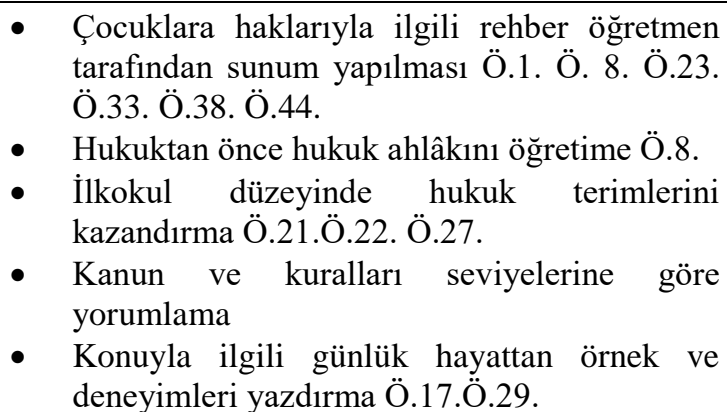 & $\begin{array}{ll}\text { - } & \text { Adil davranma için örnek olay etkinlikleri yapma } \\
& \text { Ö.2. Ö.5. Ö.7. Ö.32. Ö.34. Ö.37. } \\
\text { - } & \text { Kişisel hak ve özgürlüklere saygılı olmaları için } \\
& \text { oyun, drama gibi etkinlikler yapma (Ö.3. Ö.6.Ö.7. } \\
& \text { Ö.25. Ö.29. Ö.31.Ö.35.Ö.42 } \\
\text { - } & \text { Mahkeme sürecinin sınıfta canlandırılması Ö.19. } \\
\text { - } & \text { Poster ve afiş̧̧̧alı̧ması Ö.20. } \\
\text { - } & \text { Adalet sarayına gezi düzenleyerek farkındalık } \\
& \text { kazandırma (Ö.22. Ö.27. Ö.39.) } \\
\text { - Sinıf seçimleriyle adalet ve eșitlik kavramlarını }\end{array}$ \\
\hline
\end{tabular}


- Temel haklar ve tüketici hakları konusunda bilinçlendirme (Ö.44.)

- Bir etkinlik yaptırmadım Ö.10.Ö.16.Ö.22.Ö.25.)
(Ö.4. verme, okul ve sınıf kurallarını birlikte oluşturma Ö.35.

Hak, hukuk, adalet kavramları üzerine münazara ve tartı̧̧ma yapma Ö.3. Ö.30.Ö.36.

\section{Karşılaşılan sorunlar}

\begin{tabular}{|c|c|c|}
\hline Veliden kaynaklanan & Öğrenciden kaynaklanan & $\begin{array}{l}\text { Öğretim programı, çevre, okul ve } \\
\text { öğretmenden kaynaklanan }\end{array}$ \\
\hline 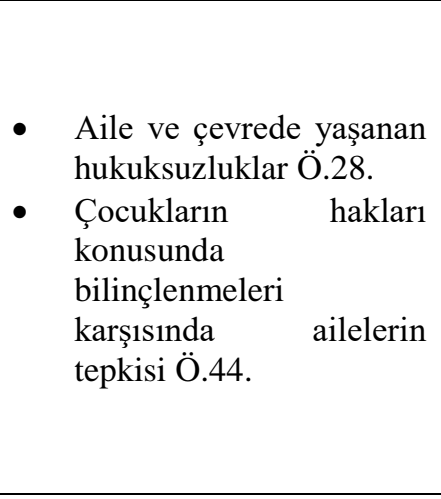 & $\begin{array}{ll}\text { - } & \text { Arkadaşlarının hakkına saygı } \\
\text { göstermeme Ö.6. } \\
\text { - } \\
\text { Tartışmaları çabuk biterek bir } \\
\text { sonuca varamama Ö.30. } \\
\text { - } \quad \text { Haklarının farkında olmama Ö.31. } \\
\text { - Ailede sürekli susturulup } \\
\text { bastırılan çocukların haklarını } \\
\text { aramaya istekli olmamaları Ö.37. } \\
\text { - Hak ve adalet konusunda aşırı } \\
\text { kurallaştırma yaparak her olayda } \\
\text { haksızlı yapıldığını düşünmeleri } \\
\text { Ö.44. } \\
\end{array}$ & $\begin{array}{ll}\text { - } & \text { Zaman yetersizliği Ö.32. } \\
\text { - } & \text { Konunun bu sınıf düzeyinde } \\
& \text { soyut olması Ö.23. Ö.26. } \\
& \text { Ö.27.Ö.33. Ö.34. Ö.35. Ö.36. } \\
\text { - } & \text { Konuları sadece bilgi } \\
& \text { düzeyinde kalması Ö.1.Ö.13. } \\
\text { - } & \text { Müfredat içeriğinde hukukla } \\
& \text { ilgili bilginin çok sınırlı olması } \\
& \text { Ö.14.Ö.19. } \\
\text { - } & \text { Materyal eksikliği anlam } \\
\text { kargaşası ve kaynak azlığı } \\
\text { Ö.32. }\end{array}$ \\
\hline
\end{tabular}

Tablo 4'e bakıldığında öğretmenlerin öğrencilere hukuk okur yazarlığı becerisi kazandırmak amacıyla yaptıkları etkinlikler teorik ve pratik, olmak üzere iki alt kategoriye, karşılaştıkları sorunlar ise veliden, öğrenciden ve öğretim programı, okul ve öğretmenden kaynaklanan sorunlar olmak üzere üç alt kategoriye ayrılarak analiz edilmiştir. Bunlardan teorik anlamda en çok çocuklara haklarıyla ilgili rehber öğretmen tarafindan sunum yapılması, konuyla ilgili günlük hayattan örnek ve deneyimleri yazdırma; pratik olarak ise en çok oyun, drama gibi etkinlikler, konu ile ilgili örnek olay incelemesi yapma ve adalet sarayına gezi düzenleme etkinliklerinin yapıldığı görülmektedir. Sorunlar sayıca en çok olanlarına bakıldığında; aile ve çevrede yaşanan hukuksuzlukların hukukla ilgili kavramların algılanmasını zorlaştırması, çocuk hakları konusunda bilinçlenen çocukların davranışları karşısında ailelerin tepkisi, öğrencilerin arkadaşlarının hakkına saygı göstermemesi, haklarının farkında olmaması ve gündelik hayatta yaşadıkları sorunları bu yolla çözmenin mümkün olamayacağı inancını taşımaları olarak gösterilmektedir. İlaveten konuların sadece bilgi düzeyinde kalması ve müfredat içeriğinde hukukla ilgili bilginin çok sınırlı olduğu vurgulanmaktadır. Öğretmenlerin görüşlerinden bazıları aşağıda gösterilmiştir.

Ö.35: ...Sinıfta seçimleri oy kullanarak yapmak. Kişisel hak ve özgürlüklere saygllı olmaları için oyun, drama gibi etkinlikler yapmak.

Ö.39: ...Sosyal bilgiler dersinden sonra adliye sarayına düzenlediğimiz gezi sonucu avukat, savcı, hakim gibi hukuki işlerde görev alan kişileri ziyaret ederek farkındalık kazandırmaya çalıştık. 
YYÜ Eğitim Fakültesi Dergisi (YYU Journal of Education Faculty), 2021; 18(1)733-765,http://efdergi.yyu.edu.tr,

Ö.6: Arkadaşının hakkına saygı göstermemeleri, oyunda kaybettiğinde yenilgiyi kabullenmeme, seçimi kaybettiğinde arkadaşlarını suçlama gibi.

Ö.37: Hakkını hukukunu savunmada aciz ve çekingen olmak. Başkalarından yardım beklemek. En önemlisi hayır deme cesareti olmamast.

Araştırmaya katılan öğretmenlerin sosyal bilgiler öğretim programında yer alan politik okuryazarlık becerisini kazandırma konusunda yaptıkları etkinlikler ve uygulama sırasında karşılaştıkları sorunlarla ilgili görüşleri Tablo 5’te sunulmuştur.

Tablo 5. Politik okuryazarlığı becerisi kazandırmak amacıyla yapılan uygulamalar ve uygulama sırasında karşılaşılan sorunlar

\begin{tabular}{|c|c|c|c|}
\hline \multicolumn{4}{|c|}{ Yapılan etkinlikler } \\
\hline \multicolumn{2}{|c|}{ Teorik } & \multicolumn{2}{|r|}{ Pratik } \\
\hline \multicolumn{2}{|c|}{ 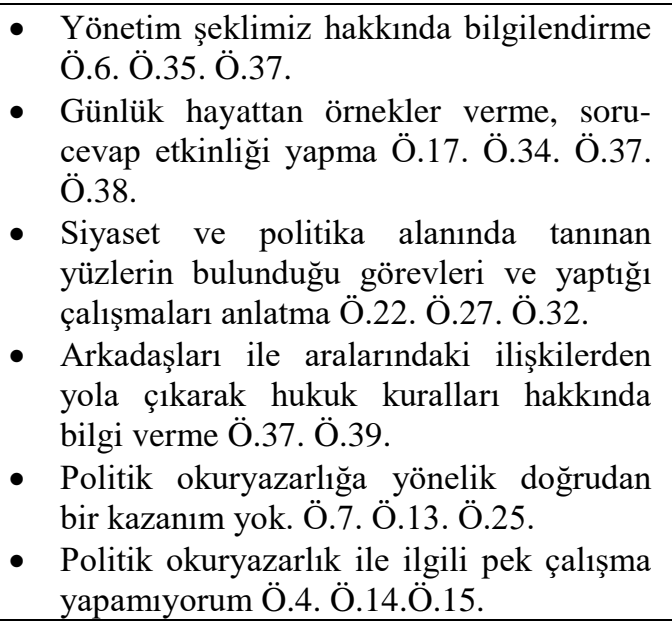 } & \multicolumn{2}{|c|}{ 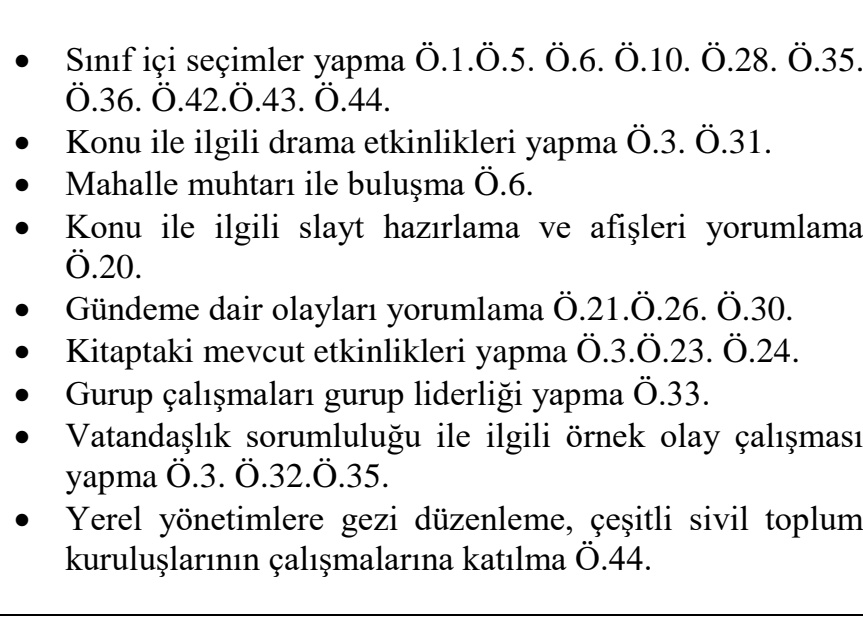 } \\
\hline $\begin{array}{c}\text { Veliden } \\
\text { kaynaklanan }\end{array}$ & \multicolumn{2}{|c|}{ Öğrenciden kaynaklanan } & $\begin{array}{l}\text { Öğretim program, çevre, okul ve } \\
\text { öğretmenden kaynaklanan }\end{array}$ \\
\hline 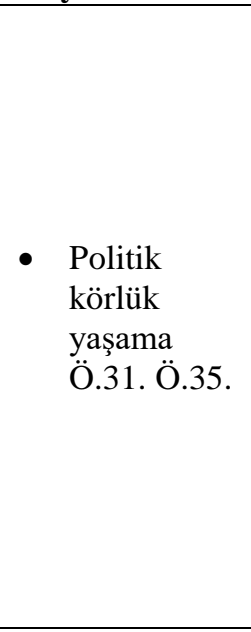 & $\begin{array}{ll}\text { - } & \text { Kararsızlı Ö.1. } \\
\text { - } & \text { Yersiz söz ve davranış } \\
& \text { Ö.44. } \\
\text { - } & \text { Politik davranış ser } \\
& \text { saklamama Ö.9. } \\
\text { - } & \text { Yorum yapmakta sıkınt } \\
\text { - } & \text { Okumaya karşı ilgisizl } \\
& \text { Ö.35. } \\
\text { - } & \text { Algilama zorluğu Ö.32. } \\
\text { - } & \text { Liderlik vasfı fazla } \\
& \text { liderliğini kabul etmem } \\
\text { - TV ve internet etkisind } \\
\text { - Özgüven eksikliği, } \\
\\
\text { göre imtiyazlı görme } \\
\text { sinıfta dişlanma Ö.39. }\end{array}$ & $\begin{array}{l}\text { bulunma Ö.8.Ö.39. } \\
\text { leyememe ve sır } \\
\text { yaşama Ö.18. } \\
\text { ve isteksizlik Ö.30. } \\
\text { anların birbirlerinin } \\
\text { eri Ö.33. Ö.36. } \\
\text { kalma. Ö.35. } \\
\text { ndisini başkalarına } \\
\text { avranışından dolayı }\end{array}$ & $\begin{array}{l}\text { - Konu ile ilgili becerilerin daha } \\
\text { çok TV'den kazanılması Ö.14. } \\
\text { - Konuları seviyeye uygun } \\
\text { olmaması Ö.21.Ö.23. Ö.35. } \\
\text { - Her öğrencinin ilgisini çekmeme } \\
\text { Ö.26. Ö.34. } \\
\text { - Çok fazla terim olması Ö.34. } \\
\text { - Öğgrencilerde kavram eksikliği } \\
\text { Ö.34. Ö.37. } \\
\text { - Öğretmenin sinıfta demokratik } \\
\text { bir ortam oluşturamamas Ö.42. } \\
\text { Ö.43. } \\
\text { - Yerel yönetimlerden randevu } \\
\text { almada zorluk yaşama Ö.44. }\end{array}$ \\
\hline
\end{tabular}

Tablo 5'e bakıldığında öğretmenlerin öğrencilere politik okuryazarlık becerisi kazandırmak amacıyla yaptıkları etkinlikler teorik ve pratik, olmak üzere iki alt kategoriye, karşılaştıkları sorunlar ise veliden, öğrenciden ve öğretim programı, okul ve öğretmenden 
kaynaklanan sorunlar olmak üzere üç alt kategoriye ayrılarak analiz edilmiştir. Bunlardan öğretmenler teorik anlamda en çok günlük hayattan örnekler verme, soru-cevap etkinliği yapma, siyaset ve politika alanında tanınan yüzlerin bulunduğu görevleri ve yaptığı çalışmaları anlatma, yönetim şeklimiz hakkında bilgilendirme olarak belirtilmiştir. Pratik olarak ise en çok sınıf içi seçimler yapma, konu ile ilgili slayt hazırlatma ve afişleri ve gündeme dair olayları yorumlama gibi etkinlikleri yaptıkları görülmektedir. Sorunlar sayıca en çok olanlarına bakıldığında; öğrencilerin okumaya karşı ilgisizlik ve isteksizlik göstermeleri, liderlik vasfi fazla olanların birbirlerinin liderliğini kabul etmemeleri, konuların konuların seviyeye uygun olmaması, her öğrencinin ilgisini çekmemesi ve öğretmenin sınıfta demokratik bir ortam oluşturamaması olarak vurgulanmıştır. Öğretmenlerin görüşlerinden bazıları aşağıda gösterilmiştir.

Ö.6: Sınıf başkan adaylarının kendini tanıtmak amacıyla konuşma yapmaları, yönetim şeklimiz hakkında bilgilendirmek. Mahalle muhtarının sınıfta öğrencilerle buluşturmak

Ö.44: Sınıf başkanı seçmek, kaymakamlı, belediye vs. yerel yönetimlere gezi düzenleme, Tema Vakfi etkinliklerine katılma, çeşitli sivil toplum kuruluşlarına katılma, çocuk hakları konusu üzerine eğilme.

Ö.35: Öğrenciler bu konuya çok ilgi göstermiyor. Nedeninin soyut kalması olduğunu düşünüyorum. TV ve internet etkisinde çok kallyorlar. Aile ne düşünüyorsa o düşünce çocuklarda hakim oluyor.

Araştırmaya katılan öğretmenlerin sosyal bilgiler öğretim programında yer alan konum analizi becerisini kazandırma konusunda yaptıkları etkinlikler ve uygulama sırasında karşılaştıkları sorunlarla ilgili görüşleri Tablo 6' da sunulmuştur.

Tablo 6. Konum analizi becerisi kazandırmak amacıyla yapılan uygulamalar ve uygulama sırasında karşılaşılan sorunlar

\begin{tabular}{|c|c|}
\hline \multicolumn{2}{|r|}{ Yapılan etkinlikler } \\
\hline Teorik & Pratik \\
\hline $\begin{array}{l}\text { - Harita üzerinde görsel etkinlikler } \\
\text { yapma Ö.5. Ö.38. } \\
\text { - Okulun bulunduğu konuma göre } \\
\text { tarım, ticaret bilgileri verme } \\
\text { Ö.14. } \\
\text { - Konuyu kısaca anlatıp özetleme } \\
\text { Ö.9. Ö.26. Ö.30. } \\
\text { - Küre üzerinde konum bilgisini } \\
\text { anlatma Ö.27.Ö.39. } \\
\text { - Navigasyon hakkında bilgi verme } \\
\text { Ö.19. }\end{array}$ & $\begin{array}{l}\text { - } \quad \text { Konum bilgisinden yararlanarak kroki çizimi yapma Ö.1.Ö.3. } \\
\text { Ö.33. Ö.35. Ö.44. } \\
\text { • } \quad \text { Ders kitabındaki etkinlikleri yapma Ö.3., Ö.4. } \\
\text { • } \quad \text { İnternet üzerinden bazı uygulamaları kullanma Ö.4 } \\
\text { • } \text { Ögrencilerin yaşadı̆ı̆1 çevreye yönelik etkinlikler düzenleme Ö.6. } \\
\text { Ö.9. Ö.21. Ö.28. Ö.31. } \\
\text { - Yön bulma yöntemleri ile ilgili etkinlikler yapma Ö.10. Ö.17. } \\
\text { Ö.39. } \\
\text { - Konu ile ilgili film izletme Ö.20 } \\
\text { - Google Earth uygulamasını kullanma Ö.22. Ö.27. Ö.34. Ö.35. } \\
\text { Ö.36. Ö.37. }\end{array}$ \\
\hline
\end{tabular}


- Gözlem resmi ve kuşbakışı gözlem, şablonlar yaptırma Ö.28.

- Haritada şehir ilçe bulma vb. oyun oynama Ö.2. Ö.3. Ö.13.Ö.35. Ö.37. Ö..39.

- İnteraktif oyunlarda mekanizmalarda kullanılan parçaların konumunu tahmin edip bulma, haritalardan yararlanarak yön bulma Ö.37

- Akıllı tahta veya öğretmenin hazırladığı materyallerden yararlanarak bir yerin konumunu bulma Ö.42. Ö.43.

- Kroki üzerinde yer tarifi yapma, akıllı telefondan gidilecek bir yerin konumunu bulma Ö.44.

\begin{tabular}{|c|c|c|}
\hline \multicolumn{3}{|c|}{ Karşılaşılan sorunlar } \\
\hline $\begin{array}{c}\text { Veliden } \\
\text { kaynaklanan }\end{array}$ & Öğrenciden kaynaklanan & $\begin{array}{c}\text { Öğretim program, çevre, okul ve öğretmenden } \\
\text { kaynaklanan }\end{array}$ \\
\hline - Belirtilmemiştir & $\begin{array}{ll}\text { - } & \text { Tablo, grafik, } \\
\text { diyagram harita } \\
\text { okuma gibi konularda } \\
\text { yetersizlik Ö.7. Ö.26. } \\
\text { Ö.28. } \\
\text { - } \quad \text { Çekingen olma. Ö.9. } \\
\text { - } \quad \text { Ülkelerin hangi yer } \\
\text { ve konumda } \\
\text { olduğunu anlamakta } \\
\text { zorluk yaşama Ö.22. } \\
\text { Ö.27. Ö.39. } \\
\text { - } \quad \text { Gereken önemi } \\
\text { vermeme Ö.30. }\end{array}$ & $\begin{array}{l}\text { - } \text { Matematik dersinde yer alan uzamsal ilişkilerle ilgili } \\
\text { kazanımların yeterli düzeyde kazanılamaması Ö.7. } \\
\text { - Konunun yaş grubu için uygun olmaması Ö.1. } \\
\text { Ö.3.Ö.4. Ö.7. Ö.13.Ö.33. Ö.34. Ö.37.Ö.39. } \\
\text { - Kitaplarda konu ile ilgili yeterli etkinlik olmaması } \\
\text { Ö.7. } \\
\text { - Har çocuğun görsel hafızasının iyi olmaması Ö.5. } \\
\text { - Yön bulma yöntemlerini gerçek yaşamda } \\
\text { uygulayacak ortam olmaması Ö.10. Ö.14. } \\
\text { - Çevrede navigasyon kullananların sayısının az } \\
\text { olması Ö.19. } \\
\text { - Çevre şartlarının elverişli olmaması Ö.21. Ö.31. } \\
\text { - Zaman ve ders saatinin az olması Ö.32. } \\
\text { - Yaşadıkları bölge dışına çıkmadıklarından şehir, ilçe } \\
\text { v e il kavramlarını kavrayamama Ö.35, Ö.36. } \\
\text { - Öğretmenin öğrencilere yetecek düzeyde yön bilgisi } \\
\text { kazandıramaması Ö.42.Ö.43. Ö.44. }\end{array}$ \\
\hline
\end{tabular}

Tablo 6'ya bakıldığında öğretmenlerin öğrencilere konum analizi becerisi kazandırmak amacıyla yaptıkları etkinlikler teorik ve pratik, olmak üzere iki alt kategoriye, karşılaştıkları sorunlar ise veliden, öğrenciden ve öğretim programı, çevre, okul ve öğretmenden kaynaklanan sorunlar olmak üzere üç alt kategoriye ayrılarak analiz edilmiştir. Bunlardan öğretmenler teorik anlamda en çok küre üzerinde konum bilgisini anlatma etkinliği yaptıkları görülmektedir. Pratik olarak ise en çok Google Earth uygulamasını kullanma, haritada şehir, ilçe bulma oyunu, konum bilgisinden yararlanarak kroki çizimi ve pusulayla yön bulma etkinliklerinin yapıldığı görülmektedir. Sorunlar sayıca en çok olanlarına bakıldığında; öğrencilerin tablo, grafik, diyagram harita okuma gibi konularda yetersiz olmaları ve ülkelerin hangi yer ve konumda olduğunu anlamakta zorluk yaşamaları, matematik dersinde yer alan uzamsal ilişkilerle ilgili kazanımları yeterli düzeyde kazanamamaları; öğretmenin öğrencilere yetecek düzeyde yön bilgisi kazandıramaması, çevre şartlarının elverişli olmaması ve öğrencilerin yaşadıkları bölge dışına çıkmadıklarından şehir, ilçe ve il kavramlarını 
kavrayamaması olarak vurgulanmıştır. Öğretmenlerin görüşlerinden bazıları aşağıda gösterilmiştir.

Ö.3: Haritadan il bulma oyunu. Google Eart'dan ülkemiz ve diğer ülkelere göre konumunu inceleme, interaktif oyunlarda mekanizmalarda kullanılan parçaların konumunu tahmin edip bulma etkinlikleri yapıyoruz.

Ö.44: ... Verilen kroki üzerinde yer tarifi yapma, verilen konuma göre kroki üzerinde yönleri kullanarak yer belirleme, akıllı telefon üzerinden gidilecek bir yerin konumunu bulma.

Ö.39: Erken yaşta başlayan çocukların soyut düşünmelerinin gelişmemiş olması, coğrafya ile ilgili terimlere yabancı kalmaları.

\section{Tartışma ve Sonuç}

$\mathrm{Bu}$ bölümde, araştırma bulguları, ilgili literatür bağlamında tartışılmış ve bazı sonuçlara ulaşılmıştır. Öğretmenler dijital okuryazarlık becerisi kazandırmak amacıyla en çok konuyla ilgili video ve belgesel izlettiklerini, olumsuz görüntü ve sosyal paylaşımların zararlarını anlattıklarını, ders ile ilgili slayt hazırlatıp sunu yaptırdıklarını; araştırma-inceleme ve bilginin paylaşımı amacıyla bilgisayar kullanıldığını ve Morpa Kampus yazılım programından destek aldıklarını vurgulanmışlardır. Uygulama sırasında veliden yeterince destek alamadıklarını ve velilerin müdahalesinin olumsuz sonuçlara yol açtığını belirtmişlerdir. Bununla birlikte, öğrencilerin bilgisayarı amacına uygun kullanmadıklarını; internet erişiminde aksaklıklar yaşandığını, alt yapı, materyal sorunu, herkesin bilgisayarının olmaması ve zaman yetersizliği gibi sorunların olduğunu dile getirmişlerdir.

Dijital okuryazarlık özellikle çocukların ve gençlerin günümüzde ve gelecekte ekonomik, sosyal, kültürel yaşamda ve vatandaşlıkla ilgili aktif rol almalarına katkıda bulunacak bilgi, beceri ve anlayış kazandırmaktadır (Hague ve Payton, 2010: s. 2-3). Dijital vatandaşlık da bir bakıma dijital okuryazarlığın bir şekli olarak görülmektedir. Dolayısıyla her birey dijital vatandaşlığın gereğini yerine getirmek için dijital okuryazar olmak zorunda kalmaktadır (MEB; 2018; Mossberger, Tolbert ve McNeal, 2007; Ribble, 2015). İnternet kullanımına paralel olarak dijital okuryazarlık düzeyinde de artış görülmektedir (Dönmez, 2019). Ancak, Yontar (2019) tarafından öğretmen adaylarının dijital okuryazarlık düzeylerini belirlemek amacıyla yapılan çalışmada dijital okuryazarlık düzeylerinin orta düzeyde olduğu sonucuna ulaşılmıştır. Literatürdeki bazı araştırmaların (Çetin, Çalışkan ve Menzi, 2012) benzer sonuçlara ulaştığı görülmektedir. Bu durum bir bakıma yeni yetişen öğretmenlerin 
dijital okuryazarlık yönünden eksik yetiştiklerini göstermektedir. $\mathrm{Bu}$ araştırmanın sonuçları ile literatürdeki araştırmaların sonuçları arasında bazı yönlerden benzerlikler olduğu söylenebilir. Özellikle ilkokul öğretmenlerinin öğrencilere dijital okuryazarlık kazandırması ve bu konuda yaşanan sorunlar konusunda literatürde araştırmaya rastlanmadığı için yorum yapılamamıştır.

Öğretmenler finansal okuryazarlık becerisi kazandırmak amacıyla en çok konu ile ilgili video izletme, alış-verişle ilgili drama yaptırma, öğrencilere ailesinin ve kendi bütçesini oluşturma ve kumbara oluşturma etkinliklerini yaptırdıklarını belirtmişlerdir. Velilerin çocuklarına yeterince yardımcı olmamaları, yeterli sorumluluk vermemeleri; öğrencilerin harcama konusunda yeterince bilinçli olmamaları ve tasarruf eğilimlerinin çok düşük olması, süre yetersizliği gibi sorunlarla karşılaştıklarını vurgulamışlardır. Alan yazına bakıldığında, PISA, finansal okuryazarlığın bireylerin ve toplumun finansal refah düzeyini artırmak açısından çok önemli yere sahip olduğunu vurgulamaktadır (OECD, 2012). Bu beceriyi kazanmak amacıyla sosyal bilgiler öğretim programında öğrencilere gelir, gider, bütçe, üretim, dağıtım, tüketim ve meslek gibi kavramları kullanarak öğrencilerin yakın çevresindeki ekonomik faaliyetleri gözlemlemesi ve raporlaştırılması ile ilgili çalışmalar yapmaları önerilmiştir (MEB, 2018). Ayrıca öğrencilerin girişimci ve bilinçli tüketicilik becerilerinin geliştirilmesi, sınırlı olan ülke kaynaklarının korunması ve geliştirilmesine yönelik olumlu tutum geliştirme, arkadaşları ile kendi ekonomik durumunu mukayese etme, meslekleri gelecekte yapacağı meslek tercihi açısından inceleme ve bulunduğu yerin ekonomik şartlarını gözden geçirerek geliştirmeye yönelik çaba gösterme gibi özelliklerin kazanılması beklenmektedir (MEB, 2017). Bu yüzden finansal okuryazarlık eğitimine bazı ülkelerde ilkokul düzeyinde müstakil ders olarak başlanmaktadır (Orton, 2007). Bazı ülkelerde ise bu beceri sosyal bilgiler, vatandaşlık, matematik, ekonomi ve sanat dersleri ile bağlantılı olarak kazandırılmaya çalışılmaktadır (Schug \& Hagedon, 2005). Bu becerinin farklı ülkelerde bir yaşam becerisi olarak görülmesi ile birlikte aktif vatandaşlı̆̆ın önemli göstergelerinden biri olarak kabul edildiği ve bu doğrultuda bir eğitim-öğretim anlayışı takip edildiği görülmektedir (Adalar, 2019). Konu ile ilgili yapılan bir araştırmaya göre finansal eğitim alan bireylerin bu eğitimi almayanlara göre daha fazla gelire sahip oldukları, daha fazla tasarruf yaptıkları, borçları iyi yönettikleri, finansal olarak kendilerine güven düzeylerinin yüksek olduğu ve tüketici haklarını daha iyi bildikleri tespit edilmiştir (Capuano \& Ramsey, 2015, s. 35-36). Johnson (2012) ilköğretim öğrencilerinin zaman, para, enerji ve bilgi gibi kıt kaynakları kullanmaları konusunda aldıkları kararların sonuçlarını uygun şekilde değerlendiremediklerini 
tespit etmişledir. Diğer bir araştırma sonucunda küçük yaşlarda olan bir grup çocuğa iyi organize edilmiş bir eğitim verildiğinde öğrencilerin ekonomi ve finansla ilgili bazı kavramları çok daha iyi öğrendikleri sonucuna ulaşmışlardır (Shug ve Hagedorn, 2005, s. 70). Yalçınkaya ve Er'e göre (2019) finansal okuryazarlık becerisi kazandırmak için yalnızca sınıfta verilen salt bilgilerle yetinilmemeli; sınıf dışında bankalar, ticaret odaları, ekonomik kuruluşlar, pazar yerleri ve marketler gibi kuruluşlara geziler düzenlenmelidir. Ay ve Yavuz (2016) yaptıkları çalışmada sınıf öğretmenlerinin konu ile ilgili olarak en çok tutumluluk üzerinde durdukları, doğal kaynakların etkili kullanımı ile bilgi düzeyinde bazı çalışmalar yaptıkları ve nadir olarak kurum, kuruluş ve fabrikalara götürme gibi sınıf dışı etkinlikler yaptıklarını tespit edilmişlerdir. Başka bir çalışmada (Akhan, 2010) öğretmenler, öğrencilere uyguladıkları finansal okuryazarlık çalışmalarının bilişsel olarak etkili olmakla birlikte günlük yaşama uygulama noktasında birçok eksiklikler olduğu ortaya konmuştur. Alan yazına bakıldığında finansal okuryazarlık becerisi kazandırma noktasında bu araştırmaya katılan öğretmenlerin yaptıkları çalışmalarla önemli düzeyde benzerlikler görünmektedir. Özellikle sınıf dışı etkinlikler konusunda bazı eksikliklerin olduğu, yapılan çalışmaların öğrencilerin davranışlarına yeterince yansımadığg sadece bilgi düzeyinde kaldığı, okulların bu konudaki çabalarının yeterli olmadığı ve öğretim programının öğretmenlere yeterince yol göstermediği söylenebilir.

Öğretmenler girişimcilik becerisi kazandırmak amacıyla en çok çeşitli iş kollarında öncü olan kişilerden örnekler verme, maddi kazanç sağlamanın faydalarını anlatma, drama yaptırma, çevre ile ilgili proje hazırlatma, güncel sorunlar üzerinde tartışma gibi etkinlikler yaptırdıklarını belirtmiş̧lerdir. Bununla birlikte, özgüven verme konusunda ailelerin katkıda bulunmaması, öğrencilerin etkinliklere katılmaya istekli olmaması, zaman yetersizliği ve bazı öğretmenlerin öğrencinin özgün fikirler üretmesini engellemesi gibi sorunlarla karşılaştıklarını vurgulamışlardır. Girişimcilik becerisi sosyal bilgiler öğretim programında bilim, teknoloji ve toplum öğrenme alanı ile ilişkilendirilmiştir. Programda bu beceriyi kazandırmak amacıyla örnek girişimciler ve onların başarı öyküleri üzerinde durulması önerilirken; bu beceriyle bireyin düşüncelerini eyleme dönüştürmesi için planlama yapması, risk alması, proje yönetme yeteneği kazanması yaratıcılığını geliştirmesi amaçlandığı vurgulanmaktadır. Ayrıca herkesin yalnızca evde ve toplumda değil işlerine ait bağlam ve şartların farkında olabilmeleri ve iş firsatlarını yakalayabilmeleri bu becerinin göstergeleri olarak belirtilmektedir (MEB, 2018). Avrupa Komisyonu (2007) raporunda, girişimcilik eğitiminin öğrenciler üzerinde olumlu etkisi olduğunu belirtilmiştir. Van Praag, Huber \& 
Sloof'a (2012) göre girişimcilik doğuştan kazanılan bir özellik değil, ancak öğrenmeyle kazanılan bir beceridir. İlkokul çağındaki çocuklara kazandırılacak girişimcilik becerisi ticari anlamda kullanılan girişimcilikten ziyade; o yaş düzeyinde okul ortamında yakalayacağı fırsatları fark etme, mevcut kaynakları organize etme, proje üretme ve ürettiği projeleri hayata geçirmek için gerekli özveri ve çabayı gösterme becerilerini ihtiva etmektedir (MEB, 2009).

Çelikkaya (2011) araştırmasında öğretmenlerin sosyal bilgiler dersinin girişimcilik becerilerinden meslekleri ve çevresindeki iş yerlerini tanıma becerisini çok kazandırdıkları sonucuna ulaşmıştır. Yurtseven ve Ergün'ün (2018) araştırmasında öğretmenler, öğrencilere girişimcilikle ilgili temel kavramların kazandırılması gerektiğini belirtmişlerdir. Öğretim sürecinde ise drama, canlandırma-rol oynama, proje yöntemi, beyin firtınası, probleme dayalı öğrenme-problem çözme ve araştırma-inceleme gibi yöntem ve tekniklerin kullanılması gerektiğini vurgulamışlardır. Bacanak'ın (2013) çalışması da bu sonucu destekler niteliktedir. Selanik Ay ve Acar (2016) ise çalışmasında sınıf öğretmenlerinin girişimciliği geliştirmek için drama, grup çalışması, kendini ifade etme, sınıfa uzman kişi davet etme, gezi, kurum ziyareti, araştırma ödevleri ve röportaj etkinlikleri yapıldığı ortaya konmuştur. Konu ile ilgli olarak yapılan bazı araştırömalarda öğretmenlerin, probleme dayalı öğrenme, durumların deneyimsel ve pratik açıklamaları yöntemlerini çok kullanmakla birlikte öğrencilere sorumluluk ve öz yönetim becerileri kazandırdıkları tespit edilmiştir. Bu bağlamda alış-veriş iş kurmaya yönelik drama çalışmaları, projeler geliştirme, girişimci kişilerle seminer ve söyleşiler yapma, yaptıkları ürünleri sergileme, tanıtma ve satma, afiş broşür tasarlama gibi etkinliklerin yapılabileceğini belirtmişlerdir (Polat, Koçak, Çermik, Meral ve Boztaş, 2015; SeikkulaLeino, Satuvuori, Ruskovaara \& Hannula 2015). Paço ve Palinhas (2011) ise öğrencilere girişimcilik becerisi kazandırmak amacıyla probleme dayalı öğrenme etkinlikleri kullanmıştır. Alan yazınla bu araştırmanın sonuçları karşılaştırıldığında kısmen benzerlikler olmakla birlikte; bu çalışmaya katılan öğretmenlerce girişimcilik kavramının yeterince anlaşılmadığı ve buna bağlı olarak yapılan çalışmaların yeterli olmadığı söylenebilir.

Yurtsever ve Ergün'ün (2018) ilkokul öğretmenleri ile yaptıkları araştırmada öğretim programındaki girişimcilikle ilgili konu ve kazanımların yetersiz olduğu, programın esnek olmadığı, etkinliklerin ve etkinliklere ayrılan sürelerin yeterli omladığı, konu ve kazanımların öğrenciler açısından soyut olduğu ve somut yaşantılarla dyeterince desteklenmediği, konuların ilgi çekici olmadığı ve yoğun olduğu belirtilmiştir. Polat ve diğerleri, 2015) de yaptığı çalışmada benzer sonuçlara ulaşmıştır. Konu ile ilgili bazı araştırmalarda velilerin ilgisiz olması, öğrenci sayısının fazla olması, eğitim araçlarının yetersizliği, okulun ekonomik 
ve fiziki açıdan yetersiz olması ve bu becerilerin kazandırılmasında öğretmenlerin yetersiz olduğu sonucuna ulaşılmıştır (Akyürek ve Şahin, 2013; Bacanak, 2013). Alan yazında ortaya konan veli, öğrenci, öğretmen ve programdan kaynaklanan sorunlarla bu çalışmada belirtilen sorunlar arasında önemli düzeyde benzerlikler olduğu söylenebilir.

Öğretmenler, hukuk okuryazarlığı becerisi kazandırmak amacıyla en çok, haklarıyla ilgili rehber öğretmen tarafından sunum yapılması, konuyla ilgili günlük hayattan örnek ve deneyimleri yazdırma, oyun, drama gibi etkinlikler yaptırma, konu ile ilgili örnek olay incelemesi yaptırma ve adalet sarayına gezi düzenleme gibi etkinlikler yaptıklarını belirtmişlerdir. Ayrıca aile ve çevrede yaşanan hukuksuzlukların hukukla ilgili kavramların algılanmasını zorlaştırdığını ifade etmişlerdir. Bununla birlikte, öğrencilerin arkadaşlarının hakkına saygı göstermemesi, haklarının farkında olmamaları, konunun bu sınıf düzeyinde soyut olması, konuların sadece bilgi düzeyinde kalması ve müfredat içeriğinde hukukla ilgili bilginin çok sınırlı olması gibi sorunlarla karşılaştıklarını vurgulamışlardır.

Hukukla ilgili kavramlar soyut olduğu için somutlaştırılmasına katkıda bulunacak sınıf içi ve sınıf dışı öğrenme- öğretme ortamları oluşturmak gerekmektedir. Sınıf içinde kitap, tahta bilgisayar ve projeksiyon cihazları; sınıf dışında adliyede mahkeme ortamlarına katılma, yerel yönetim merkezlerine gezi düzenlenmesi gibi etkinlikler yapılabilir (Oğuz, 2015). Ay ve Yavuz'un (2016) yaptığı çalışmaya göre sınıf öğretmenleri hukuk okur yazarlığı bağlamında en fazla öğrencileri okul kurallarına uymaya teşvik etme, tüketici hakları konusunda bilgilendirme gibi etkinlikleri yaptıkları tespit edilmiştir. Ayrıca trafik polisi uygulaması gibi uygulamalarla çevrelerindeki insanları ve ailelerini kurallara uyma konusunda yönlendirme ve mesleki etik konusunda öğrencilerin bilgilendirilmesini sağlama uygulamalarının çok az yapıldığı sonucuna ulaşılmıştır. Bu araştırmanın sonucu ile ilgili literatür arasında kısmen benzerlikler görülmekle birlikte, bu becerinin ilkokul düzeyinde soyut kaldığı, konunun öğretmenler tarafından yeterince anlaşılmadığı; bazı öğretmenlerce becerinin kazandırılmasına yönelik kısmi etkinlikler yapılsa da yeterli olmadığı söylenebilir. Bununla birlikte öğretim programının öğretmenlere yeterince rehberlik etmediği ne yapılması gerektiği konusunda belirsizlikler olduğu anlaşılmaktadır.

Öğretmenler, politik okuryazarlık becerisi kazandırmak amacıyla en çok günlük hayattan örnekler verme, siyaset ve politika alanında tanınan yüzlerin bulunduğu görevleri ve yaptığı çalışmaları anlatma, yönetim şeklimiz hakkında bilgilendirme ve arkadaşları ile aralarındaki ilişkilerden yola çıkarak hukuk kuralları hakkında bilgi verme, sınıf içi seçimler yapma, sınıf başkanı adayı olarak propaganda konuşması yapma, konu ile ilgili slayt 
hazırlama, afişleri ve gündeme dair olayları yorumlama gibi etkinlikler yaptıklarını belirtmişlerdir. Bununla birlikte öğrencilerde okumaya karşı ilgisizlik, isteksizlik ve liderlik vasfi fazla olanların birbirlerinin liderliğini kabul etmemeleri, konuların seviyeye uygun olmaması, her öğrencinin ilgisini çekmemesi ve öğretmenin sınıfta demokratik bir ortam oluşturamaması gibi sorunlar yaşadıklarını vurgulamışlardır.

Tam (2016) politik okuryazarlık ile ilgili olarak sınıfta öğrencilerle herhangi bir fikri empoze etmeden tartışmalı politik konular üzerinde değerlendirmeler yapılmasının etkili olacağını belirtmiştir. Konu ile ilgili yapılan bir araştırmaya göre tartışmalı konulara yer verilen sınıflarda bu tartışmalara katılan öğrencilerin sonraki hayatlarında siyasi haberleri izleme, boykota katılma, dilekçe imzalama gibi faaliyetlere katılma konusunda daha istekli oldukları tespit edilmiştir. Ayrıca düzenli olarak sınıf içi tartışmalara katılan öğrencilerin sonraki hayatlarında oy kullanma, demokratik değerleri destekleme, siyasi tartışmalara katılma, medyada siyasi haberleri takip etme ve kamu politikalarını etkileme gibi aktiviteler gösterebilecekleri vurgulanmıştır (McCully \& Barton, 2007). Ay ve Yavuz'un (2016) yaptıkları çalışmada öğretmenlerin politik okuryazarlık bağlamında en çok gerçek bir seçim atmosferi oluşturarak sınıf başkanlığı seçimi yapma, öğrencileri sınıftaki karar verme süreçlerine katma gibi uygulamalara yer verdiklerini tespit etmiştir. Sivil toplum kuruluşlarının temsilcilerini sınıfa davet etme, sivil toplum kuruluşlarının çalışmalarına katılma faaliyetlerini ise en az gerçekleştirdiklerini ortaya koymuştur. Bu araştırma konu ile ilgili alan yazında yer alan çalışmalar arasında benzerlikler olmakla birlikte genel olarak öğretmenlerin beceriyi nasıl kazandıracakları, ne yapacakları konusunda kafa karışıklığı yaşadıkları, programın kendilerini yeterince aydınlatamadığı söylenebilir.

Öğretmenler, konum analizi becerisi kazandırmak amacıyla en çok küre üzerinde konum bilgisini anlatma, Google Earth uygulamasını kullanma, haritada şehir ilçe bulma vb. oyunu, konum bilgisinden yararlanarak kroki çizimi yapma, pusulayla yön bulma, vb. etkinlikleri yaptıklarını belirtmişlerdir. Ancak, uygulama esnasında öğrencilerin tablo, grafik, diyagram harita okuma gibi konularda yetersiz olması, matematik dersinde yer alan uzamsal ilişkilerle ilgili kazanımların yeterli düzeyde kazanılamaması, öğretmenin öğrencilere yetecek düzeyde yön bilgisi kazandıramaması, çevre şartlarının elverişli olmaması ve yaşadıkları bölge dışına çıkmadıklarından şehir, ilçe ve il kavramlarını kavrayamamaları gibi sorunlarla karşılaştıklarını vurgulamışlardır. Ay ve Yavuz'un (2016) konu ile ilgili yaptığı çalışmada öğretmenlerin yön bulma ile ilgili etkinlikler yaptırdıkları, öğrencilere kroki çizdirmeye çalıştıkları tespit edilmiştir. Bununla birlikte oryantiring uygulamaları ve Google Haritalar 
uygulamaları az yaptıkları tespit etmiştir. Öğretmenlerin sınıf dışı etkinlik ve teknolojik imkanlardan yararlanma konusunda önemli eksiklikleri olduğu ortaya konmuştur. Akengin ve Ayaydın (2017) yaptıkları çalışmada çizdikleri krokilere göre öğrencilerin mekanla ilgili algılarını belirlemeye çalışmışlardır. Araştırmanın sonucunda öğrencilerin çizdikleri krokilerde günlük ihtiyaçlarını karşıladıkları okul, market, kırtasiye, fırın gibi mekânlara yer verdikleri tespit edilmiştir. İlgili literatürle bu çalışmanın sonucu arasında benzerlikler olduğu görülmektedir. Konum analizi becerisi kazandırılması açısından öğretmenlerin konuyla ilgili yeni teknolojileri kullanma konusunda yeterli olmadıkları, yeterli olan ögretmenlerin beceriyi kazandırmada daha etkili oldukları söylenebilir.

\section{Öneriler}

Becerilerin kazandırılması konusunda, sosyal bilgiler öğretim programında öğretmenleri aydınlatıcı yeterli açıklama ve uygulama örneklerine yer verilmeli; uygulamalı seminer ve kurslar düzenlenmelidir. Sosyal bilgiler programına ayrılan haftalık ders saati, becerilerin kazandırılmasına harcanacak süre de dikkate alınarak yeniden düzenlenmelidir. Okul yönetimleri, becerilerin kazandırılması ile ilgili yapılacak okul içi ve okul dışı etkinlikler konusunda öğretmenlere gerekli katkı ve desteği sağlama konusunda bilgilendirilmelidir. Becerileri gerçekleştirme konusunda materyal sıkıntısı yaşayan okullara ve öğrencilere gerekli destek sağlanmalıdır.

\section{Makalenin Bilimdeki Konumu}

İlköğretim/Sosyal bilgiler eğitimi

\section{Makalenin Bilimdeki Özgünlüğü}

$\mathrm{Bu}$ araştırma sosyal bilgiler öğretim programında yer alan bazı becerilerin kazandırılması konusunda öğretmenlerin kafa karışıklığı yaşadıkları ve uygulamada problemlerle karşılaştıkları yönündeki iddialardan yola çıkılarak yapılmıştır. Literatürde konu ile ilgili yeterli çalışma olmaması üzerine alana katkı sunmak amacıyla böyle bir çalışmanın yapılmasına ihtiyaç durulmuştur.

\section{Kaynaklar}

Adalar, H. (2019). Finansal okuryazarlık. B. Aksoy, B. Akbaba ve B. Kilcan. (Ed.) Sosyal bilgilerde beceri ĕgitimi (149-182). Ankara: Pegem Akademi.

Akengin, H. ve Ersoy, F. (2015). Sosyal bilgiler eğitiminde mekansal öğrenme ortamlarının tarihçesi. Ramazan Sever ve Erol Koçoğlu (Ed.), Sosyal bilgiler Eğitiminde Mekansal Öğrenme Ortamları (s. 17-40). Ankara: Pegem Akademi. 
Akengin, H., ve Ayaydın, Y. (2017). Mekânı Algılama ve zihin haritalarının geliştirilmesi üzerine bir araştırma. Marmara Coğrafya Dergisi, 36, 48-56.

Akhan, N. E. (2010). İlköğretim Sosyal bilgiler öğrencilerinde ekonomi okuryazarlı̆̆ının durumu ve geliştirilmesi. (Yayımlanmamış Doktora Tezi) Gazi Üniversitesi / Eğitim Bilimleri Enstitüsü, Ankara.

Akyürek, Ç. ve Şahin, Ç. (2013). Evaluation of elementary teachers’ entrepreneurship skills. Ekev Akademi Dergisi, 17(57), 51-68.

Alkaya, A. ve Yağlı, İ. (2015). Finansal okuryazarlık-finansal bilgi, davranış ve tutum: Nevşehir Hacı Bektaş Veli Üniversitesi İ̈BF Öğrencileri Üzerine Bir Uygulama. Uluslararası Sosyal Araştırmalar Dergisi, 8, 585-599.

Avrupa Komisyonu. (2007). Key competences for lifelong learning-a 73 european a framework. Luxembourg: Office for Official Publications of the European Communities.

Ay, T.S., Yavuz, Ü. (2016). Sınıf öğretmenlerinin sosyal bilgiler dersinde okuryazarlık becerilerini kazandırmaya yönelik gerçekleştirdikleri uygulamalar. Anadolu Journal of Educational Sciences International, 6(2), 31-63.

Bacanak, A. (2013). Fen ve teknoloji dersinin öğrencilerde girişimcilik becerisinin gelişimine etkisi üzerine öğretmen görüşleri. Kuram ve Uygulamada Ĕ̆itim Bilimleri. 13(1), 609629.

Büyüköztürk, Ş., Çakmak-Kılıç, E., Akgün, Ö. E., Karadeniz, Ş. ve Demirel, F. (2012). Bilimsel araştırma yöntemleri (13. baskı). Ankara: Pegem Akademi.

Capuano, A. ve Ramsay, I. (2011). What causes suboptimal financial behaviour? an exploration of financial literacy, Social Influences and Behavioural Economics, Financial Literacy Project, Research Report, The Universitiy of Melbourne.

Creswell, J. W. (2013). Nitel araştırma yöntemleri: Beş yaklaşıma göre nitel araştırma ve araştırma deseni. Ankara: Siyasal Kitabevi.

Çepni, O. (2015). Konum analizi. B. Aksoy, B. Akbaba, B. K1lcan. (Ed.). Sosyal bilgilerde beceri eğitimi (367-386). Ankara: Pegem Akademi.

Çetin, O., Çalışkan, E. ve Menzi, N. (2012). Öğretmen adaylarının teknoloji yeterlilikleri ile teknolojiye yönelik tutumları arasındaki ilişki. İlköğretim Online, 11(2), 273-291,

Çelikkaya, T. (2011). Sosyal bilgiler programında yer alan becerilerin kazandırılma düzeyi: Öğretmen görüşleri. Kastamonu Ĕ̆itim Dergisi, 19 (3), 969-990. 
Cohen, L., Manion, L., ve Morrison, K. (2007). Research methods in education (6th ed.). Routledge/Taylor \& Francis Group.

Dönmez, G. (2019). Lise ögrencilerinin bilgi güvenliği farkındalı̆̆ı ile dijital okuryazarlı̆̆ arasındaki ilişkinin incelenmesi. (Yayınlanmamış Yüksek Lisans Tezi). Hacettepe Üniversitesi / Eğitim Bilimleri Enstitüsü.

Gençtürk, E., ve Karatekin, K. (2013). Sosyal bilgiler için çoklu okuryazarlıklar. Ankara: Pegem Akademi.

Gömleksiz, M. N., ve Kan, A. Ü. (2009). Sosyal bilgiler dersi öğretim programının eleştirel düşünme, yaratıcı düşünme ve girişimcilik becerilerini kazandırmadaki etkililiğinin belirlenmesi (Diyarbakır ili örneği).Fırat Üniversitesi Doğu Araştırmaları Dergisi, 8(1), 39-49.

Güvenç, H. (2015). Finansal okuryazarlı: PISA ve Jumpstart koalisyonu bireysel finans eğitimi standartlarının karşılaştırılması. II. International Eurasian Educational Research Congress / 2. Uluslararası Avrasya Eğitim Araştırmaları Kongresi, Ankara.

Hague, C. ve Payton, S. (2010). Digital literacy across the curriculum. Erişim tarihi: 14.11.2020, https://www.nfer.ac.uk/publications/FUTL06/FUTL06.pdf.

johnson, T., L.(2012). Exploring the options: teaching economic decision-making with poetry. The Social studies.103, 61-66.

Martin, A. (2005). DigEuLit-a European framework for digital literacy: a progress report. Journal of eLiteracy, 2 (2), 130-136.

McCully, A. W., ve Barton, K. C. (2007). Teaching controversial 1ssues. where controversial issues really matter. Teaching History, 127(127).

MEB, (2004). Sosyal bilgiler 4.-5. sınıf ögretim programı: Ankara.

MEB (2005). İlkögrretim sosyal bilgiler dersi ögretim programı ve kılavuzu (4-5. Sinıflar): Ankara.

MEB, (2009). Ortaöğretim girişimcilik dersi öğretim programı. Ankara: Milli Eğitim Basımevi.

MEB (2018). İlköğretim sosyal bilgiler dersi öğretim programı: Ankara.

Miles, M. B., \& Huberman, A. M. (1994). Qualitative data analysis: An expanded sourcebook. (2nd ed). Thousand Oaks: CA Sage.

Mossberger, K., Tolbert, C., and S. McNeal, R. (2007). Digital citizenship: the internet, society and participation. London, England: The MIT Press. 
OECD. (2012). Finansal eğitim ulusal stratejisi üst düzey ilkeleri. Organisation for economic co-operation and development : Paris.

Oğuz, S. (2015). Sosyal bilgiler eğitiminde hukuksal mekanlara dayalı öğrenme ortamları. R. Sever ve E. Koçoğlu (Ed.). Sosyal bilgiler eğitiminde mekanlara dayalı öğrenme ortamlarl (s.157-180). Ankara: Pegem.

Orton, L. (2007). Financial literacy: Lessons from international experience. Canadian Policy.

Paço, A. D. \& Palinhas, M. J. (2011). Teaching entrepreneurship to children: A casestudy. Journal of Vocational Education \& Training, 63(4), 593-608.

Patton, M. Q. (2005). Qualitative research. New York: John Wiley \& Sons, Ltd.

Polat, S., Koçak, B., Çermik, F., Meral, E. ve Boztaş, M. (2015). İlköğretim sosyal bilgiler ders kitaplarının girişimcilik kazanımı açısından öğretmen görüşlerine göre değerlendirilmesi. EKEV Akademi Dergisi, 62, 455-470.

Ribble, M. (2015). Digital citizenship in schools: Nine elements all students should know. International Society for Technology in Education.

Selanik Ay, T. \& Acar, Ş. (2016). Sınıf öğretmenlerinin girişimcilik becerisi kazandırmaya ilişkin görüşleri. Elektronik Sosyal Bilimler Dergisi, 15(58), 960-976.

Seikkula-Leino, J., Satuvuori, T., Ruskovaara, E. \& Hannula, H. (2015). How do Finnish teacher educator simplement entrepreneurship education?. Education+ Training, 57(4), 392-404.

Schug, M. and Hagedorn, E. A. (2005). The money savvy pigtm goes to the big city: testing the effectiveness of an economics curriculum for young children. The social studies, 96 (2), 68-71.

Senemoğlu, N. (2001). Gelişim, ögrenme ve ögretim. Ankara: Gazi Kitabevi.

Sözen, E., ve Ada, S. (2005). 2005 ve 2018 4. sınıf sosyal bilgiler dersi öğretim programlarının (SBDÖP) karşılaştırılması. Anadolu Ĕgitim Liderliği ve Öğretim Dergisi, 6(1), 53-71.

Tam, H. (2016). Political literacy and civic thougtfulness. John O'Brien \& Simon Dufy (E.).

Tarhan, Ö. (2015). Sosyal bilgiler öğretmeni adaylarının politik okuryazarlığına ilişkin görüşleri. Akademik Sosyal Araştırmalar Dergisi, 3(9), 649-669.

Tay, B. (2017). 2005 Sosyal bilgiler dersi öğretim programı ile 2017 sosyal bilgiler dersi taslak öğretim programının karşılaştırması. International Journal Of Eurasia Social Sciences, 8(27), 461-487.

TDK (1932). Türk Dil Kurumu sözlügüu, https://sozluk.gov.tr/, Erişim tarihi: 09.05.2020. 
Ürper, Y. (2015). Girişimcilik kavramı, çeşitleri ve girişimcilikte etik. (s. 2-21) Girişimcilik

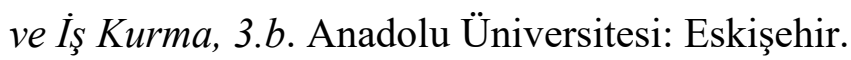

Van Praag, C. M., Huber, L. R. \& Sloof, R. (2012). The effect of early entrepreneurship education: evidence from a randomized field experiment. (No. 7612). IZA Discussion Paper.

Vogt, W. P., Gardner, D. C., \& Haeffele, L. M. (2012). When to use what research design. New York: Guilford Press.

Yalçınkaya, E. ve Er, T. (2019). Sosyal bilgiler eğitiminde finansal okuryazarlık. Nevşehir Hacı Bektaş Veli Üniversitesi SBE Dergisi, 9(1), 1-24.

Yıldırım, A. ve Şimsek, H. (2011). Sosyal bilimlerde nitel araştırma yöntemleri (8. baskı). Ankara: Seçkin Yayınevi.

Yontar, A. (2019). Öğretmen adaylarının dijital okuryazarlık düzeyleri. Ana Dili Eğitimi Dergisi, 7(4), 815-824.

Yurtseven, R. ve Ergün M. (2018). İlkokul öğrencilerinin girişimcilik becerilerinin geliştirilmesine yönelik öğretmen görüşleri. International Journal of Social Science Research, 7(1), 118-140. 


\section{Summary}

\section{Statement of Problem}

In the 2005 social studies curriculum, it was aimed to provide the students with some skills in line with today's needs. While it is aimed to provide students with more information in social studies curricula before 2005, it has become important to construct knowledge by students and to implement the learned knowledge in the new curriculum. In this context, the products that emerge at the end of the processes in which cognitive and psychomotor learning take place together are called skills (MEB, 2005).

Curriculum is a detailed plan that shows the purpose, level, duration, application and evaluation stages of the knowledge, skills and attitudes to be acquired by students. In addition, there is an answer to the question of what to teach in order to achieve the goals in the curriculum. In this context, some skills foreseen to be acquired by students in the current social studies curriculum are included (MEB, 2018). In the curriculum, these skills are associated with field acquisitions, and it is emphasized that the teacher should gain the skills according to this association. There are limited studies on the matching of skills and acquisitions in the curriculum and the competence of teachers to gain skills in terms of acquisition of skills. This research has emerged on the expressions and observations that the teachers have difficulty experiences in understanding and applying some skills in the social studies curriculum.

The aim of this research is to determine what is expected from teachers in the implementation of the program, whether the skills are realized as required, the way teachers understand these skills, and the activities for skill acquisition. In this regard, it is aimed to share the good examples while determining the situation.

\section{Method}

In the research, it was carried out in order to identify and share the activities of teachers for the acquisition of skills in the social studies curriculum and the problems they encounter in practice. In this respect, the research is a qualitative research in the case study design. The research carried out with 44 teachers (31 independent classes, 13 multi-class classes) working in the schools (primary school, primary school with independent-joined classrooms). The teachers voluntarily participated in the research in Unye District of Ordu Province, in the 2019-2020 academic year. Easily accessible case sampling which one of the purposeful sampling methods used in the research. The data analysis is performed to using 
content analysis. In order to ensure reliability, the consistency between the codes given by more than one researcher was taken as a basis. The agreement percentage formula was used to calculating the stability (Miles \& Huberman, 1994). The agreement percentage was determined as 0.83, and this value considered sufficient (Yildirim \& Şimşek, 2011).

\section{Findings}

The activities that teachers do to help the students gain literacy skills are divided into two sub-categories as theoretical and practical. The problems faced by the teachers were analyzed by dividing them into three sub-categories as problems arising from parents, students and curriculum, environment, school and teachers. The teachers have emphasized that they mostly benefited from watching videos and documentaries, using time effectively, having students prepare slides and making presentations, and Morpa Campus software program in order to gain digital literacy skills.

In order to gain financial literacy skills, they organize activities such as watching videos, making drama about shopping, creating family and own budget, and creating a piggy bank. In order to gain entrepreneurship skills, they mostly carry out activities such as giving examples from people who are pioneers in various business lines, revealing new things and explaining the benefits of financial gain, preparing environmental projects and supporting students who are candidates for the election of the school council president.

In order to gain legal literacy skills, teachers have mostly organized the activities such as making presentations to students about their rights by their counselors, getting them to comprehend legal terms at primary school level, doing activities such as games and drama, case studies and trips to the court of justice.

In order to provide students with political literacy skills, teachers are doing some activities which giving examples from daily life, questions and answers, explaining the tasks and works of well-known people in the field of politics and politics, informing about the management style and legal rules, making in-class choices, they organize activities such as making propaganda speeches as a candidate for the class president, preparing slides and interpreting posters and events related to the agenda, and doing case studies on citizenship responsibility.

In order to give students, the ability to analyze the location, the teachers do the activities which explain the location information on the globe, use the Google Earth application, find the city district on the map, draw a sketch using the location information, 
find direction with the compass, use the smart board or they conduct discovery with the materials they have prepared activities.

\section{Discussion and Conclusion}

In order to provide students with digital literacy skills, teachers carry out activities such as watching videos and documentaries about the subject and getting support from the Morpa Campus software program. However, they encounter the problems such as not getting enough support from parents, using the computer out of its purpose, not having a computer for every student, and lack of time. There are studies with similar findings in the literature (Cetin, Caliskan \& Menzi, 2012). In order to provide students with financial literacy skills, teachers make activities such as watching videos about the concepts of saving, budget, income and expenditure, drama about shopping, creating family-own budget and creating a piggy bank. However, in practice, teachers encounter the problems such as parents' not giving their children enough responsibility, students not being conscious enough about spending and insufficient time allocated to the lesson. There are studies with similar findings in the literature (Yalcinkaya \& Er, 2019; Ay \& Yavuz, 2016; Akhan, 2010). In order to provide students with entrepreneurship skills, teachers are involved in activities such as giving examples from people who are pioneers in various business lines, explaining the benefits of financial gain, making drama, preparing environmental projects, and supporting students who are candidates for the election of the school council president. However, students face the problems such as unwillingness to class, lack of self-confidence and lack of time. There are similarities between the results of this research and the results of some studies in the literature (Akyurek \& Sahin, 2013; Bacanak, 2013; Baranović \& Štibrić, 2007; Polat et al., 2015; Semerci \& Yanpar Yelken, 2010; Yurtsever \& Ergün, 2018). To help the students gain legal literacy skills, teachers have organized activities such as presentations, play, drama, case studies and trips to the court of justice by the counselor. Teachers are faced with some problems such as not respecting the rights of their friends, not being aware of their own rights, being abstract according to the class level and not being willing to seek their rights in their classroom work. The results of some studies in the literature (Ay \& Yavuz, 2016; Oguz, 2015) support this research. In order to provide students with political literacy skills, teachers have conducted the activities such as explaining the duties of people known in the field of politics and politics and their work, giving information about the management style, making class president elections, preparing slides and commenting on the events related to the agenda. However, teachers encounter some problems such as students' indifference and unwillingness 
to read, and students with high leadership qualities not accepting each other's leadership. The results of the research conducted by Ay and Yavuz (2016) are similar to the results of this research. In order to gain location analysis skills to students, teachers have performed activities such as giving location information on the globe, using the Google Earth application, finding a city-district on the map, drawing a sketch, finding directions with a compass. Because students do not leave the region where they live, the teachers are faced with the problems such as not being able to fully understand the concepts of city, district and province. The results of some studies in the literature (Akengin \& Ayaydin, 2017; Ay \& Yavuz, 2016; Tuna \& Balci, 2013) support the results of this research.

\section{Ethics Committee Decision}

This research has ethic committee decision by Social and Humanities Publication Ethics Committee in Ondokuz Mayis University, with 5 Feb 2020 date and with number 2020/61. Accordingly, there is no drawback in conducting the research within the framework of the Social and Human Ethical Rules and Principles. 